\title{
Birey-temelli ve Grup-temelli Süreçlerin Kaynaşımı: Așırı Fedakâr Grup-yanlısı Davranış Sergileme Eğilimini Yordama
}

\author{
Fatih Özdemir \\ Bursa Uludağ Üniversitesi
}

\author{
Türker Özkan \\ Orta Doğu Teknik Üniversitesi
}

\begin{abstract}
Özet
Bu çalışma, "neden bazı kişiler iç-grup üyeleri uğruna kendi yaşamını feda etme gibi aşırı fedakâr davranışlarda bulunuyor" sorusunu anlamlandırmayı ve Sosyal Kimlik, Kimlik Kaynaşımı ve Göreli Yoksunluk Kuramları'ndan faydalanarak, kişilerin yerel iç-grup (Cumhuriyet Halk Partisi destekçileri), geniş iç-grup (Türkiye Cumhuriyeti vatandaşları) ve yerel dış-gruplar (Adalet ve Kalkınma Partisi, Halkların Demokratik Partisi ve Milliyetçi Hareket Partisi destekçileri) ile ilişkilerini birey ve grup seviyelerinde incelemeyi amaçlamaktadır. Araştırmaya, kendini Cumhuriyet Halk Partisi destekçisi olarak tanımlayan ve yaş ortalaması $24.72(S=4.86)$ olan 219 kadın ve 101 erkek toplam 320 kişi katılmıştır. Gruplar arası farklı durumları yansıtan 6 senaryoya ilişkin ölçümlere ek olarak, katılımcılardan grup özdeşleşmesi, kimlik kaynaşımı, birey-temelli/grup-temelli göreli yoksunluk ve göreli yoksunluk kaynaşımı ölçümleri alınmıştır. Bulgular, araştırma değişkenleri arasında anlamlı sistematik ilişkiler olduğuna işaret etmektedir. Kimlik kaynaşımı ve göreli yoksunluk kaynaşımı değişkenleri yerel iç-grup ve geniş iç-grup yararına sergilenen aşırı fedakâr davranışlarda bulunma eğilimini pozitif olarak yordamıştır. İç-grup özdeşleşmesi ve birey-temelli/grup-temelli yoksunluk değişkenleri ise aşırı fedakâr davranışları açıklamakta yetersiz kalmıştı. Araşıırma bulguları, aşırı fedakâr grup-yanlısı davranışları açıklayan kuramsal bir çerçeve sunması ve birey ve grup seviyelerinde gerçekleşen süreçlerin eş zamanlı etkin, birbiriyle örtüşmüş (kaynaşmış) ve birbirini destekleyen süreçler olduğunu göstermesi yönüyle önemlidir.
\end{abstract}

Anahtar kelimeler: Aşırı fedakâr grup-yanlısı davranışlar, grup özdeşleşmesi, kimlik kaynaşımı, göreli yoksunluk

\begin{abstract}
This study aims to rationalize the question of "why some people perform extreme self-sacrificing behaviors as sacrificing own life on the behalf of in-group members" and explore the relations of people with local in-group (Republican People's Party supporters), extended in-group (the Republic of Turkey citizens) and local out-groups (Justice and Development Party, Peoples' Democratic Party, and Nationalist Movement Party supporters) in individual and group levels on the basis of Theories of Social Identity, Identity Fusion, and Relative Deprivation. A total of 320 people, 219 women and 101 men, who defined themselves as supporter of the Republican People's Party with a mean age of $24.72(S D=4.86)$ participated in the study. Participants responded to 6 vignettes reflecting different inter-group situations and scales of group identification, identity fusion, individual-based/group-based relative deprivation, and relative deprivation fusion. Findings pointed out the significant systematic associations between study variables. Identity fusion and relative deprivation fusion variables positively predicted the tendency to perform extreme self-sacrificing behaviors on the behalf of local in-group and extended in-group. In-group identification and individual-based/group-based deprivation variables could not explain extreme self-sacrificing behaviors. It is important that research findings present a theoretical framework to explain extreme self-sacrificing pro-group behaviors and indicate individual-based and group-based processes are simultaneously salient, overlapped (fused), and mutually supportive.
\end{abstract}

Keywords: Extreme self-sacrificing pro-group behaviors, group identification, identity fusion, relative deprivation

Yazar notu: 20. Ulusal Psikoloji Kongresi'nde (Kasım, 2018) sözel bildiri olarak sunulmuştur. Bu makalenin yazımında, ilk yazarın doktora tezinden yararlanılmıştır.

Yazışma Adresi: Dr. Öğr. Üyesi Fatih Özdemir, Bursa Uludağ Üniversitesi, Fen-Edebiyat Fakültesi, Psikoloji Bölümü, 16059, Nilüfer / Bursa

E-posta: psyfatihozdemir@gmail.com

Gönderim Tarihi: 18.03.2019

Kabul Tarihi: 13.04 .2020 
Gruplar arası bir eylemlilik hali olarak tanımlanan aşırı grup-yanlısı davranışlar, grup-yararına kolektif bir amaç taşıma niteliğine sahiptir. $\mathrm{Bu}$ amaç grup-temelli bir ideolojiyi desteklemek, grubun algılanan dezavantajlı durumuna karşı çıkmak, grubun sahip olduğu mevcut imkânları iyileştirmek ya da grup üyelerini çeşitli tehlikelere karşı korumak olabilmektedir. Grup üyeleri yararına aşırı fedakâr davranış (extreme self-sacrificing pro-group behavior) sergileme eğilimi ve kişileri, aşırı grup-yanlısı davranışa yönelten motivasyonun ne olduğu farklı kuramsal yaklaşımlarla alanyazında yürütülen çalışmalarca incelenmektedir. Bu yaklaşımların başında ise kimlik-temelli ve yoksunluk-temelli kuramlar gelmektedir.

Mevcut çalıșma "neden bazı kișiler iç-grup üyeleri uğruna kendi yaşamını feda etme gibi aşırı fedakâr grup-yanlısı davranışlarda bulunuyor" sorusunu anlamlandırmayı ve Sosyal Kimlik Kuramı (Social Identity Theory; Tajfel ve Turner, 1979), Kimlik Kaynaşımı Kuramı (Identity Fusion Theory; örn. Swann, Gomez, Seyle, Morales ve Huici, 2009; Swann, Jetten, Gomez, Whitehouse ve Bastian, 2012) ve Göreli Yoksunluk Kuramı'ndan (Relative Deprivation Theory; örn. Crosby, 1976; Davis, 1959; Gurr, 1970; Runciman, 1966) faydalanarak kişilerin yerel iç-grup, geniş iç-grup ve yerel dış-gruplar ile ilişkilerini birey ve grup seviyelerinde incelemeyi hedeflemektedir. Araştırma, kendini Cumhuriyet Halk Partisi (CHP) destekçisi olarak tanımlayan kişilerin katılımıyla gerçekleşmiştir. Bu bağlamda yerel iç-grup CHP destekçilerini, geniş iç-grup Türkiye Cumhuriyeti (T.C) vatandaşlarını ve yerel dış-gruplar ise Kasım-2015 parlamento seçimleriyle Türkiye Büyük Millet Meclisi'nde temsil hakkına sahip olan Adalet ve Kalkınma Partisi (AKP), Halkların Demokratik Partisi (HDP) ve Milliyetçi Hareket Partisi (MHP) destekçilerini ifade etmektedir. Yerel iç-grup (local in-group) ve geniş iç-grup (extended in-group) kavramları grubun üye sayısına bağlı olarak, Kimlik Kaynaşımı Kuramı çerçevesinde alanyazında yürütülen çalışmalarca kullanmış kavramlardır.

\section{Kimlik-temelli Yaklaşım}

1970'lerin sonlarından beri iç-grup özdeşleşmesi kavramı ve Sosyal Kimlik Kuramı (Tajfel ve Turner, 1979) grup-yanlısı davranışları açıklamak için sıklıkla kullanılmaktadır. Sosyal grup özdeşleşmesinden kaynaklanan grup üyeliği-temelli bilgi ve duygusal bağlılık kişinin sosyal kimliğini oluşturmakta ve kişiye "ben kimim" sorusunu yanıtlayabilmesi için bir referans noktası sağlamaktadır. Ancak uluslararası güncel yayınlar dikkate alındığında, aşırı grup-yanlısı davranışları yordamak amacıyla yabancı araştırmacıların, Türkiye'de pek çalışılmamış bir yaklaşım olan Kimlik Kaynaşımı
Kuramı'na (örn. Swann ve ark., 2009; 2012) s1klıkla başvurduğu görülmektedir. Kimlik kaynaşımı kavramı "işlevsel olarak eşit, etkin ve geçirgen birey-temelli kimlik ile grup-temelli kimliğin birbiriyle örtüşme ve kişinin iç-grubu ile kaynaşma ve bir olma durumunu" (Özdemir, 2018), yani benlik ve grup arasındaki ayrılmaz bir bağ ifade etmektedir (Gomez ve ark., 2017). İç-grup özdeşleşmesi (Sosyal Kimlik Kuramı: grup-temelli kimlikle özdeşleşme) ve kimlik kaynaşımı (Kimlik Kaynaşımı Kuramı: bireysel kimlik ve grup-temelli kimliğin bağlantılı ve bir olma hali) bazı okuyucularca işlevsel olarak birbirine yakın kavramlarmış gibi algılanabilir, ancak bireysel kimlik ve sosyal kimliğin grup-yanlısı davranışlarla etkileşimi dikkate alındığında bu kavramlar arasında bazı net farklılıklar bulunmaktadır.

Sosyal Kimlik Kuramı kapsamında tartışılan işlevsel karşıklık ilkesi (functional antagonism principle) ve bireysellikten uzaklaşma hipotezi (depersonalization hypothesis) grup-yanlısı davranışları etkin sosyal kimlik/ etkinsizleşen bireysel kimlik ve kategori (özdeşleşilen grubun prototipik özellikleri)-temelli çekimle açıklamaktadır (örn. Hogg, 1993; Hogg ve Hardie, 1991; Levine ve Crowther, 2008). Kimlik Kaynaşımı Kuramı kapsamında önerilen kimlik sinerjisi (identity synergy), ilişkisel bağlar (relational ties) ve etkin bireysel öz (agentic personal self) ilkeleri ise grup-yanlısı davranışları aynı anda etkin ve işlevsel olarak birbirine eşit bireysel kimlik ve sosyal kimlik, tek olma temelli çekim ve etkin bireysellik haliyle anlamlandırmaktadır (örn. Swann ve ark., 2009; 2012; Swann, Wenzlaff ve Tafarodi, 1992). Kimlik Kaynaşımı Kuramına göre bireysel kimlik ve sosyal kimlik birbiriyle çatışmaktan ziyade birbirini desteklemekte ve aşırı grup-yanlısı davranış sergileme eğilimini kuvvetlendirmektedir.

İç-grup özdeşleşmesi ve kimlik kaynaşımı kavramları arasındaki farklar araştırma bulgularıyla desteklenmektedir (örn. Gomez ve ark., 2011; Swann, Gomez, Dovidio, Hart ve Jetten, 2010; Swann, Gomez, Huici, Morales ve Hixon, 2010). Örneğin, Buhrmester ve arkadaşları (2012) tarafından yürütülen çalışmada grup üyeliğinin getirdiği olumlu ve olumsuz çıktılar kimlik-kaynaşımlı kişiler tarafından güçlü bir şekilde bireysel bir çıktı olarak algılanırken, grupla özdeşleşmiş (kimlik-kaynaşımsız) kişiler sadece olumlu çıktıları içselleştirmiştir. Diğer çalışmalarda ise bireysel kimlik ve sosyal kimliğin etkinliği test edilmiş; kimlik-kaynaşımlı örneklemde bireysel kimlik ya da sosyal kimliğin etkinliği grup yararına aşırı fedakar davranış sergileme eğilimini yordarken, özdeşleşmiş (kimlik-kaynaşımsız) örneklemde sadece sosyal kimliğin etkinliği grup-yanlısı davranış sergileme eğilimini güçlendirmiştir (örn. Swann ve ark., 2009; Swann ve Buhrmester, 2015; Swann, Gomez ve ark., 2014; Swann, Gomez, Dovidio ve ark., 2010). Ek 
olarak, kimlik-kaynaşımlı kişiler iç-grup üyeleri tehlikede olduğunda daha yoğun endişe ve stres hissetmiş (Swann, Gomez ve ark., 2014) ve grup üyeleri yararına fedakarlıkta bulunma eğilimi sergilemiştir (Gomez ve ark., 2011; Swann ve ark., 2009). Bulgular göstermektedir ki kimlik kaynaşımlı kişiler hem birey seviyesinde hem grup seviyesinde gruba yönelik bir aidiyet ve grup üyeleri ile derin ilişkisel bağlar geliştirmektedir. Grup üyeleri sadece grubun prototipik özelliklerine göre şekillenmiş sosyal kategoriler olarak değil, aileden biri ve değerli bireyler olarak algılanmaktadır (Swann, Buhrmester ve ark., 2014). Bu durum üyeler arasında paylaş1lan birlikteliği, karşılıklı sorumluluk algısını ve kolektif bağları güçlendirmektedir (Gomez ve ark., 2011; Swann, Buhrmester ve ark., 2014).

\section{Göreli Yoksunluk-temelli Yaklaşım}

Göreli yoksunluk Kuramı (örn. Crosby, 1976; Davis, 1959; Gurr, 1970; Runciman, 1966) grup-yanlısı davranış sergileme eğilimini yordamak amacıyla kullanılan bir diğer yaklaşımdır. Kurama göre bireyler kişiler arası ya da gruplar arası karşılaştırmalar yaparak diğer kişilere kıyasla kişisel dezavatajının ya da diğer gruplara kıyasla üyesi olduğu grubun dezavantajının farkına varmaktadır. Kişiler arası ve gruplar arası öznel karşılaştırmalar farklı çıktılarla ilişkilendirilmektedir; kişiler arası karşılaştırmalar ve birey-temelli yoksunluk hali öznel esenlik, yaşam doyumu, öz-sayg1, stres ve depresyon gibi birey-temelli durumları yordarken (örn. Osborne ve Sibley, 2013; Smith ve Ortiz, 2002; Smith, Pettigrew, Pippin ve Bialosiewicz, 2012; Walker, 1999; Walker ve Mann, 1987), gruplar arası karşılaştırmalar ve grup-temelli yoksunluk hali grup-yanlısı protesto, kolektif eylem ve sosyal değişim gibi grup-temelli çıktılarla ilişkilendirilmiştir (örn. Abrams ve Grant, 2012; Walker ve Man, 1987).

Araştırmacıların çoğu benzer-seviye yaklaşımın önemine dikkat çekmekte (örn. Smith ve ark., 2012; Walker ve Mann, 1987; Walker ve Pettigrew, 1984) ve birey-temelli ve grup-temelli yoksunluklar neredeyse birbiriyle ilişkisiz süreçler olarak sunulmaktadır. Grup-yanlısı davranışların çoğunlukla grup-temelli kimlik, gruplar arası kıyaslamalar ve grup-temelli yoksunluk haliyle açıklanabileceği önerilmektedir (örn. Smith ve ark., 2012; Walker, 1999; Walker ve Mann, 1987). $\mathrm{Bu}$ durum Hogg'un makalelerinde (1987; 1991; 1993) bahsedilen bireysel ve sosyal kimliğe yönelik farklılaştırma-temelli yaklaşımı hatırlatmakta ve grup-temelli davranışlarda bireysel kimliğin, kişiler arası kıyaslamaların ve birey-temelli yoksunluğun etkisini görmezden gelmektedir. Alanyazındaki bazı çalışmalar bu görüşle tutarlı değildir. Örneğin, Pettigrew ve arkadaşları (2008) tarafından yürütülen araştırmada grup-temelli yoksun- luk, birey-temelli yoksunluk ve diş-gruba yönelik önyarg1 arasındaki ilişkide aracı değişken rolüne sahiptir. Az sayıdaki çalışma ise aynı anda oluşan birey-temelli ve grup-temelli yoksunluk hallerinin grup-yanlısı davranış sergileme eğilimini destekleyeceğini ve iç-gruba olan bağlılı̆̆ 1995; Tougas ve Beaton, 2002).

Mevcut araştırma kişiler arası ve gruplar arası k1yaslamaların ilişkili süreçler olduğunu önermektedir. Kişiler arası ve gruplar arası kıyaslamalar ve neticesinde ortaya çıkan yoksunluk halleri grup-yanlısı davranış sürecinde birbirini destekleyerek bireyin aşırı grup-yanlısı davranış sergileme eğilimini kuvvetlendirebilir. Araştırmanın alanyazın taraması ve Kimlik Kaynaşımı Kuramının varsayımları dikkate alındığında mevcut çalışma, kişiler arası kıyaslamaların ve birey-temelli yoksunluk halinin gruplar arası kıyaslamalar ve grup-temelli yoksunluk haliyle örtüştüğü ve kaynaştığ 1 , göreli yoksunluk kaynaşımı olarak adlandırılan yeni bir kavram önermektedir.

Bulgulara göre bireyler, iç-grubun dezavantajlı durumunu fark etseler dahi, kendilerini bu dezavantaja maruz kalıyor olarak algılamayabilmekte (Taylor, Wright, Moghaddam ve Lalonde, 1990) ve bu durum, kişilerin grup-temelli davranış sergileme eğilimini azaltabilmektedir (Taylor, Moghaddam, Gamble ve Zellerer, 1987). Fakat mevcut araştırmada birey ve grup seviyesindeki yoksunluk halinin örtüşmesi ve kaynaşımı nedeniyle, birey-temelli algılanan adil ve meşru olmayan dezavantaj, grup deneyimleriyle ilişkili olacaktır ve bireyler algılanan grup-temelli dezavantaja, kişisel hayatlarında da maruz kalacaktır. Kimlik Kaynaşımı Kuramı ve ilgili alanyazın dikkate alındığında (örn. Stets ve Burke, 2000; Swann ve ark., 2009; 2012; Swann, Gomez, Huici ve ark., 2010) bu durum, iç-grup üyeleri arasında alg1lanan benzerliği ve ilişkisel bağlılığı artırabileceği gibi, iç-grup üyeleri uğruna aşırı fedakar davranış sergileme eğilimini kuvvetlendirebilir.

\section{Çalışmaya Genel Bakış}

Kendini CHP destekçisi olarak tanımlayan kişilerin oluşturduğu bir örneklemde yürütülen bu çalışma, kat1lımcıların yerel iç-grup (CHP destekçileri), geniş iç-grup (T.C vatandaşları) ve yerel dış-gruplarla (AKP, HDP ve MHP destekçileri) olan ilişkilerini incelemektedir. Çalışma kimlik-temelli ve yoksunluk-temelli yaklaşımları kullanarak yerel iç-grup ve geniş iç-grup üyeleri yararına kendi hayatını feda etme gibi aşırı fedakâr davranış sergileme eğilimini anlamlandırmayı amaçlamaktadır. $\mathrm{Bu}$ bağlamda araştırmanın desteklediği temel görüş birey ve grup seviyelerinde gerçekleşen süreçlerin (bireysel kimlik ve sosyal kimlik; birey-temelli yoksunluk ve grup-temelli yoksunluk) aynı anda etkin ve birbiriyle 
ilişkili olabileceği ve yine bu süreçlerin birbirini destekleyerek aşırı grup-yanlısı davranış sergileme motivasyonunu kuvvetlendirebileceğidir. Bu bağlamda test edilen araştırma hipotezleri şöyle sıralanmaktadır:

Hipotez 1. Yerel iç-grup ve geniş iç-grupla kimlik kaynaşımı yerel iç-grup ve geniş iç-grup yararına aşırı fedakâr davranış sergileme eğilimini pozitif olarak yordayacaktır. Yerel iç-grup ve geniş iç-grupla özdeşleşme hallerinin aşırı grup-yanlısı davranış sergileme eğilimini yordama gücü ise daha düşük ya da anlamsız olacaktır.

Hipotez 2. Göreli yoksunluk kaynaşımı yerel içgrup ve geniş iç-grup yararına aşırı fedakâr davranış sergileme eğilimini pozitif olarak yordayacaktır. Ayrı seviyelerdeki birey-temelli ve grup-temelli göreli yoksunluk hallerinin aşırı grup-yanlısı davranış sergileme eğilimini yordama gücü ise daha düşük ya da anlamsız olacaktır.

\section{Yöntem}

\section{Örneklem}

Araştırmaya, kendini Cumhuriyet Halk Partisi destekçisi olarak tanımlayan 320 kişi katılmıştır. Katılımciların 219'u kadın (\%68.4), 101'i erkektir (\%31.6). Örneklemin yaş dağılımı 18 ve 37 arasında değişirken, yaş ortalaması 24.72 yıldır $(S=4.86)$. Katılımcıların 234 'ü lisans (\%73.1) ve 86's1 lisansüstü (\%26.9) eğitim seviyesine sahiptir. Örneklemin algilanan sosyo-ekonomik statü ortalaması ise "en alt statü" ve "en üst statü" arasında değişen 7li Likert tipi ölçümde $4.24(S=.87)$ olarak bulunmuştur.

\section{Veri Toplama Araçarı}

Vinyetler. Yerel iç-grup, geniş iç-grup ve yerel dişgrup üyelerini korumak amacıyla kişinin aşırı fedakâr davranış sergileme eğilimini test eden vinyetler Swann ve arkadaşları (Swann, Gomez ve ark., 2014; Swann, Gomez, Dovidio ve ark., 2010) tarafindan geliştirilmiş ve bu araştırma kapsamında makale yazarlarınca Türkçe'ye uyarlanmıştır (bkz. Tablo 1). Bu araştırmada yerel iç-grup, katılımcıların desteklediği siyasi parti olan CHP'nin destekçilerini, geniş iç-grup T.C vatandaşlarını ve yerel dış-gruplar ise Kasım-2015 parlamento seçimleriyle mecliste temsil hakkına sahip olan AKP, HDP ve MHP'nin destekçilerini ifade etmektedir.

Yazarlarca Türkçe'ye çevrilen ve çoklu-siyasi parti düzlemine uyarlanan 6 vinyetten ilk ikisinde sosyal kimlik (örn. beş yerel iç-grup üyesi tehlike altındadır: "kontrolden çıkmış bir tramvay beş CHPli'ye çarpmak ve ölümlerine neden olmak üzeredir.") ve bireysel kimlik (örn. sen tehlike altındasın: "kontrolden çıkmış bir tramvay sana çarpmak ve ölümüne neden olmak üzeredir.”) aktivasyon sırası değiştirilmiş ve yerel iç-grup üyelerinin hayatını kurtarmak için katılımcıların aşırı fedakâr davranış sergileme eğilimi test edilmiştir. İlk vinyette katılımcılar "tramvayı durdurmak için hiçbir şey yapmama ve beş CHPli'nin ölümüne izin verme" ya da "beş CHPli'nin hayatını kurtarmak için kendi hayatını feda etme" seçeneklerinden birini seçmiştir. İkinci vinyette ise "beş CHPli'yi yardım için çağırma ve kendi hayatını kurtarmak için bu kişilerin ölümüne neden olma" ya da "kendi hayatını feda etme" seçeneklerinden birini tercih etmişlerdir.

Üçüncü vinyette, beş geniş iç-grup üyesinin yaşamına karşı bir yerel iç-grup üyesinin yaşamı ikilemi ve kişinin aşırı fedakâr davranış sergileme eğilimi test edilmiştir. Vinyete göre kontrolden çıkmış bir tramvay beş T.C vatandaşına çarpmak üzeredir. Katılımcılar "tramvayı durdurmak için hiçbir şey yapmama ve beş T.C vatandaşının ölümüne izin verme", "beș T.C vatandașının hayatını kurtarmak için kendi hayatını feda etme" ya da “tramvayın yönünü değiştirerek bir CHPli'nin ölümüne neden olma ve beş T.C vatandaşının hayatını kurtarma" seçenekleri arasında bir tercihte bulunmuştur.

Dördüncü, beşinci ve altıncı vinyette ise, beş geniş iç-grup üyesinin yaşamına karşı beş yerel dış-grup üyesinin yaşamı ikilemi ve kişinin aşırı fedakâr davranış sergileme eğilimi incelenmiştir. Vinyette, paralel demiryolunda kontrolden çıkmış iki tramvay beş T.C vatandaşına ve beș AKPli'ye / beș HDPli'ye / beș MHPli'ye çarpmak ve ölümlerine neden olmak üzeredir. Katılımcılar "tramvayı durdurmak için hiçbir şey yapmama ve beş T.C vatandaşının ve beş AKPli'nin / beş HDPli'nin / beş MHPli'nin ölümüne izin verme", "beş T.C vatandaşını kurtarmak için kendi hayatını feda etme ve beș AKPli'nin / beş HDPli'nin / beș MHPli'nin ölümüne izin verme" ya da "beş AKPli’yi / beş HDPli'yi / beş MHPli'yi kurtarmak için kendi hayatını feda etme ve beş T.C vatandaşının ölümüne izin verme" seçeneklerinden birini tercih etmiştir.

Grup Özdeşleşmesi Ölçümü. Tek faktörlü (6-madde) ölçek Mael ve Ashforth (1992) tarafından kişinin kendini bir grupla ne derece özdeşleştirdiğini ölçmek amacıyla geliştirilmiştir. Ölçeğin iç-tutarlılık katsayıs1 .83 olarak bulunmuştur.

Türkçe'ye çevrilen ve bu araştırmaya uyarlanan ölçeğin bazı maddeleri “CHPliler'den/T.C vatandaşlarından bahsederken genellikle onlar yerine biz diye bahsederim," "Birisi CHPliler'i/T.C vatandaşlarını yücelttiğinde sanki bana övgüde bulunmuş gibi hissederim" şeklindedir (bkz. Ek Tablo 1). "Diğer siyasi partilerin üyelerinin CHPliler/Diğer milletlerin T.C vatandaşlar1 hakkında ne düşündügüyle çok ilgiliyim" ifadesi ise düşük madde-toplam korelasyonu ve sorunlu iç tutarl1lık katsayısı nedeniyle araştırmaya dahil edilmemiştir. Katılımcılardan, kendi siyasi parti destekçilerini ve T.C vatandaşlarını referans almaları ve kendilerini bu iki 
Tablo 1. Vinyetler ve CHP Destekçilerinin Yanıtları

Vinyet 1. Altından trenyolu geçen bir üst geçitte olduğunuzu düşünün. Beş CHPli'nin aşağıdaki raylarda mahsur kaldığını ve kontrolden çıkmış bir tramvayın bu beş CHPli'ye çarpmak üzere hızla yaklaştığını görüyorsunuz. Hiçbir şey yapmayıp tramvayın CHPliler'e çarpmasına izin verebilirsiniz ya da raylara atlayıp kendi hayatınızı feda etme pahasına tramvayın yavaşlayıp durmasını sağlayarak CHPliler'i kurtarabilirsiniz. Bu durumda ne yaparsınız?

a. Hiçbir şey yapmayıp tramvayın geçmesine izin veririm ve beş CHPli hayatını kaybeder.

$N(\%)$
$180(\% 56.2)$
$140(\% 43.8)$

b. Hayatımı feda etme pahasına, tren yoluna atlayıp tramvayın yavaşlayıp durmasını sağlarım ve beş CHPli'nin hayatını kurtarırım.

Vinyet 2. Tren raylarında mahsur kaldığınızı ve kontrolden çıkmış bir tramvayın hızla size doğru yaklaştığını düşünün. 200 metre ileride beş CHPli'nin olduğunu ve eğer onlara seslenirseniz size yardım için geleceklerini fark ediyorsunuz. Bu beş CHPli hızla yaklaşan tramvayın farkında değiller. Yardım için geldiklerinde siz ve tramvay arasındaki raylarda kalacaklar. Böylece beş CHPli kendi hayatlarını kaybederek tramvayın yavaşlayıp durmasını sağlayacak ve siz hayatta kalacaksınız. Bu durumda ne yaparsınız?

a. Beş CHPli’yi ölüm tuzağına çekerek hayatta kalırım.

\begin{tabular}{c}
$N(\%)$ \\
\hline $133(\% 41.6)$ \\
$187(\% 58.4)$
\end{tabular}

b. Beş CHPli'ye seslenmem ve hayatımı feda ederim.

$187(\% 58.4)$

Vinyet 3. Kontrolden çıkmış bir tramvayın, beş T.C vatandaşına doğru hızla yaklaştığını görüyorsunuz. Hiçbir şey yapmazsanız bu kișiler hayatını kaybedecek. T.C vatandaşlarını kurtarmak için ya kendi hayatınızı feda etme pahasına raylara atlayıp tramvayın yavaşlayarak durmasını sağlayacaksınız ya da rayların makasıyla oynayıp tramvayın yönünü değiştireceksiniz ve diğer rayda olan bir CHPli'nin ölümüne neden olacaksınız. Bu durumda ne yaparsınız?

a. Hiçbir şey yapmam ve beş T.C vatandaşı hayatını kaybeder.

\begin{tabular}{c}
$N(\%)$ \\
\hline $74(\% 23.1)$ \\
$106(\% 33.1)$
\end{tabular}

b. Kendi hayatımı feda etme pahasına raylara atlayıp beş T.C vatandaşının hayatını kurtarırım.

c. Rayların makasıyla oynarım ve tramvayın diğer raya sapmasını sağlayarak bir CHPli’nin ölmesine neden olurken, beş T.C. vatandaşının hayatını kurtarırım.

Vinyet 4. Kontrolden çıkmış iki tramvay birbirine paralel iki trenyolunda hızla ilerlemektedir. Tramvaylardan birinin beş T.C vatandaşına, diğer tramvayın ise beş AKPli’ye çarpıp, bu kişileri öldürmek üzere olduğunu görüyorsunuz. Eğer hiçbir şey yapmazsanız, tramvaylar iki grubun da ölümüne sebep olacak. Eğer kendi hayatınızı feda etme pahasına T.C vatandaşlarının olduğu raylara atlarsanız, beş T.C vatandaşının hayatını kurtaracaksınız, fakat beş AKPli hayatını kaybedecek. Eğer kendi hayatınızı feda etme pahasına AKPliler'in olduğu raylara atlarsanız, beș AKPli'nin hayatını kurtaracaksınız, fakat bes T.C vatandașı hayatını kaybedecek. $\mathrm{Bu}$ durumda ne yaparsiniz?

a. Hiçbir şey yapmam ve iki grup da hayatını kaybeder.

$N(\%)$

b. Kendi hayatımı feda etme pahasına T.C vatandaşlarının olduğu raylara atlarım.

$189(\% 59.1)$

c. Kendi hayatımı feda etme pahasına AKPliler'in olduğu raylara atlarım.

$129(\% 40.3)$

$2(\% .6)$ 
Tablo 1 Devamı. Vinyetler ve CHP Destekçilerinin Yanıtları

Vinyet 5. Kontrolden çıkmış iki tramvay birbirine paralel iki trenyolunda hızla ilerlemektedir. Tramvaylardan birinin beş T.C vatandaşına, diğer tramvayın ise beş HDPli'ye çarpıp, bu kişileri öldürmek üzere olduğunu görüyorsunuz. Eğer hiçbir şey yapmazsanız, tramvaylar iki grubun da ölümüne sebep olacak. Eğer kendi hayatınızı feda etme pahasına T.C vatandaşlarının olduğu raylara atlarsanız, beş T.C vatandaşının hayatını kurtaracaksınız, fakat beş HDPli hayatını kaybedecek. Eğer kendi hayatınızı feda etme pahasına HDPliler'in olduğu raylara atlarsanız, beş HDPli'nin hayatını kurtaracaksınız, fakat beş T.C vatandaşı hayatını kaybedecek. $\mathrm{Bu}$ durumda ne yaparsinız?
a. Hiçbir şey yapmam ve iki grup da hayatını kaybeder.
b. Kendi hayatımı feda etme pahasına T.C vatandaşlarının olduğu raylara atlarım.
c. Kendi hayatımı feda etme pahasına HDPliler'in olduğu raylara atlarım.

\begin{tabular}{c}
$N(\%)$ \\
\hline $191(\% 59.7)$ \\
$124(\% 38.8)$ \\
$5(\% 1.6)$
\end{tabular}

Vinyet 6. Kontrolden çıkmıs iki tramvay birbirine paralel iki trenyolunda hızla ilerlemektedir. Tramvaylardan birinin bes T.C vatandaşına, diğer tramvayın ise beş MHPli’ye çarpıp, bu kişileri öldürmek üzere olduğunu görüyorsunuz. Eğer hiçbir şey yapmazsanız, tramvaylar iki grubun da ölümüne sebep olacak. Ĕ̆ger kendi hayatınızı feda etme pahasına T.C vatandaşlarının olduğu raylara atlarsanız, beş T.C vatandaşının hayatını kurtaracaksınız, fakat beş MHPli hayatını kaybedecek. Eğer kendi hayatınızı feda etme pahasına MHPliler'in olduğu raylara atlarsanız, beş MHPli’nin hayatını kurtaracaksınız, fakat beş T.C vatandaşı hayatını kaybedecek. Bu durumda ne yaparsinız?
$N(\%)$

$186(\% 58.1)$

$131(\% 40.9)$

$3(\% .9)$

Not. Vinyetlerde herhangi bir davranış opsiyonu 35 katılımcıdan daha az kişi tarafından seçildiyle, bu seçenek düşük örneklem boyutu nedeniyle analize dâhil edilmemiștir (Burns ve Burns, 2008).

grupla ne derece özdeşleştirdiklerini belirtmeleri istenmiştir. Katılımcılar, sunulan ifadeleri yanıtlarken "hiç katılmiyorum" ve "tamamen katıliyorum" arasında değişen 7'li Likert ölçeğini kullanmıştır. CHP grubu ve T.C vatandaşları referans alındığında 5 maddeli ölçümün iç tutarlılık katsayıları sırasıyla .86 ve .88 şeklindedir. Yüksek değerler referans alınan grup ile yüksek özdeşleşme halini göstermektedir.

Kimlik Kaynaşımı Ölçeği. Tek faktörlü (7-madde) ölçek Gomez ve arkadaşları (2011) tarafından bireyin kimlik kaynaşımı halini (bireysel kimlik ve grup-temelli kimliğin bağlantılı ve bir olma hali) test etmek amaciyla geliştirilmiştir. Ölçeğin iç tutarlılık değerleri .83 ve .90 arasındadir.

Türkçe'ye çevrilen ve araştırma örneklemine uyarlanan ölçeğin bazı maddeleri "CHPliler/T.C vatandaşları ile bir bütünüm," "CHPliler/T.C vatandaşları sayesinde güçlüyüm” şeklindedir (bkz. Ek Tablo 1). Katılımcılardan, kendi siyasi parti destekçilerini ve T.C vatandaşlarını referans almaları ve bu iki grupla ne derece kimlik kayna-
Şımı algıladıklarını belirtmeleri istenmiştir. Katılımcılar, "hiç katılmıyorum" ve "tamamen katılıyorum" arasında değişen 7'li Likert ölçeğini kullanarak ölçek maddelerini yanıtlanmıştır. CHP grubu ve T.C vatandaşları referans alındığında ölçümün iç tutarlılık katsayıları sırasıyla .92 ve .92 şeklindedir. Yüksek değerler referans alınan grup ile yüksek kimlik kaynaşımı halini ifade etmektedir.

Birey-temelli ve Grup-temelli Göreli Yoksunluk Ölçeği. Birey düzeyinde göreli yoksunluk ölçeği (5-madde) Özdemir, Tekeş ve Öner-Özkan (2019) tarafından geliştirilmiştir. Kişiler arası karşılaştırmalar neticesinde kișinin, birey düzeyinde, arzulanan çıktıya ilişkin ne derece yoksunluk hissettiğini test eden ölçeğin iç tutarlılık güvenirliği .71 olarak saptanmıştır.

$\mathrm{Bu}$ çalışmada kullanılan birey-temelli (5-madde) ve grup-temelli (5-madde) göreli yoksunluk alt-ölçekleri Türkiye'nin sosyo-politik düzleminde kişiler arası ve gruplar arası karşılaştırmalar sonucu, birey-temelli ve grup-temelli hissedilen yoksunlukları ölçmek amacıyla Özdemir ve arkadaşları (2019) tarafından geliştirilen öl- 
çekten uyarlanmıştır. Birey-temelli Göreli Yoksunluk Ölçeğinin bazı madddeleri "Kendimi diğer T.C vatandaşları ile karşılaştırdığımda, diğer T.C vatandaşlarının benden daha iyi sosyal ve politik imkânlara sahip olduğunun farkındayım," "Diğer T.C vatandaşlarının sahip olduğu sosyal ve politik imkânlara sahip olmayı isterim" şeklindedir. Grup-temelli Göreli Yoksunluk Ölçeğinin bazı maddeleri ise "CHPliler'i diğer T.C vatandaşları ile karşılaştırdığımda, diğer T.C vatandaşlarının CHPliler'den daha iyi sosyal ve politik imkânlara sahip olduğunun farkındayım," "Diğer T.C vatandaşlarının sahip olduğu sosyal ve politik imkânlara CHPliler'in de sahip olmasını isterim" şeklindedir (bkz. Ek Tablo 1). Katılımcılardan, sahip oldukları sosyal ve politik imkanları baz alarak, kendilerini ve grup üyesi oldukları CHP'nin destekçilerini diğer T.C vatandaşlarıyla birey ve grup seviyelerinde karşılaştırmaları ve ne derece birey-temelli ve grup-temelli yoksunluk hissettiklerini belirtmeleri istenmiştir. Bu kişiler, "hiç katılmıyorum" ve "tamamen katıllyorum” arasında değişen 7'li Likert ölçeğini kullanarak ölçek maddelerin yanıtlamıştır. Birey-temelli ve grup-temelli yoksunluk alt-ölçeklerin iç tutarlılık güvenirliği sırasıyla .85 ve .87 şeklindedir. Yüksek değerler, kendinin ya da yerel iç-grubunun sahip olduğu sosyal ve politik imkânlara bağlı olarak kişinin, yüksek seviyede birey-temelli ya da grup-temelli yoksunluk hissettiğini göstermektedir.

Göreli Yoksunluk Kaynașımı Ölçeği. Tek faktörlü (7-madde) ölçek kişinin birey-temelli ve grup-temelli göreli yoksunluk hallerinin birbiriyle bağlantılı ve bir olma durumunu ölçmek amacıyla Kimlik Kaynaşımı Ölçeği (Gomez ve ark., 2011) dikkate alınarak, makale yazarlarınca geliştirilmiştir. Ölçek maddelerinden önce katılımc1lara göreli yoksunluk, birey-temelli göreli yoksunluk ve grup-temelli göreli yoksunluk tanımları verilmiştir. Ölçeğin bazı maddeleri "CHPli grup üyeliğime bağlı grup-temelli yoksunluğum ve birey-temelli yoksunluğum bir bütündür," "CHPli grup üyeliğime bağlı grup-temelli yoksunluğumu giderdiğimde, birey-temelli yoksunluğumu da gidermiş olacağım" şeklindedir (bkz. Ek Tablo 1). Katılımcılardan birey-temelli ve yerel iç-grup-temelli göreli yoksunluklarının ne derece birbiriyle ilişkili ve kaynaşmış olduğunu belirtmeleri beklenmiştir. Bu kişiler "hiç katılmıyorum" ve "tamamen katılıyorum" arasında değişen 7'li Likert ölçeğini kullanarak ölçek maddelerini yanıtlamıştır. Ölçeğin iç tutarlılık katsayısı .94 olarak saptanmıştır. Yüksek değerler göreli yoksunluk kaynaş1mı halinin güçlü olduğunu, yani, algılanan birey-temelli dezavantajın algılanan grup-temelli dezavantajla ilişkili olduğunu ve kişilerin hem birey hem grup seviyelerinde yoksunluk hissettiğini ifade etmektedir.

Demografik bilgi formu. Bilgi formu cinsiyet, yaş, eğitim durumu ve algılanan sosyo-ekonomik statü demografik değişkenlerine ilişkin sorular içermektedir.
İşlem

Orta Doğu Teknik Üniversitesi etik kurul onayı alındıktan sonra veri, QUALTRICS yazılımı kullanılarak toplanmıştır. Kendini CHP destekçisi olarak tanımlayan kişilerin araştırmaya katılması hedeflenmiştir. Bu kişilere ulaşmak amacıyla araştırmanın duyuruları sosyal medya kanalları aracılı̆̆ıyla paylaşılmış ve Cumhuriyet Halk Partisi'nin siyasi oluşumları e-posta yoluyla araştırma hakkında bilgilendirilmiştir. Veri toplama süreci 2017 yılında yapılan anayasa referandumundan 1 gün önce (15.04.2017) sonlandırılmıştır.

\section{Bulgular}

\section{Betimleyici Bulgular}

Yerel iç-grupla (CHP destekçileri) özdeşleşme ve kimlik kaynaşımı değişkenleri arasında pozitif yönde güçlü bir ilişki vardır. Benzer ilişki geniş iç-grupla (T.C vatandaşları) özdeşleşme ve kimlik kaynaşımı değişkenleri arasında da görülmektedir. Ek olarak, yerel iç-grup-temelli kimlik değişkenleri geniş iç-grup-temelli kimlik değişkenleriyle pozitif yönde ilişkilidir. Kimlik ve yoksunluk değişkenleri dikkate alındığında ise, kimlik değişkenlerinin ayrı seviyelerdeki birey-temelli ve grup-temelli göreli yoksunluk değişkenlerine kıyasla göreli yoksunluk kaynaşımı değişkeniyle daha güçlü pozitif yönde ilișkili olduğu söylenebilmektedir. Araştırma değişkenleri arasında belirtilen ilişkiler ve değişkenlerin ortalama ve standart sapma değerleri Tablo 2'de sunulmaktadır.

\section{İç-Grup Yanlısı Aşırı Fedakâr Davranış Sergileme Eğilimini Yordama}

Katılımcıların yerel iç-grup, geniş iç-grup ve yerel dış-gruplar yararına aşırı fedakâr davranış sergileme eğilimini test etmek için gruplar arası farklı durumları yansıtan 6 senaryo kullanılmıştır. İlk ve ikinci senaryolarda katılımcının seçebileceği iki davranış opsiyonu varken, diğer senaryolarda mümkün davranış seçenekleri daha fazladır. İki seçenekli senaryolarda davranış eğilimini yordamak amacıyla hiyerarşik lojistik regresyon analizi kullanılmıştır. İlk blokta yerel iç-grupla özdeşleşme ve kimlik kaynaşımı; ikinci blokta geniş iç-grupla özdeşleşme ve kimlik kaynaşımı; üçüncü blokta birey-temelli ve grup-temelli göreli yoksunluklar; ve dördüncü blokta göreli yoksunluk kaynaşımı değişkenleri yordayıcı değişken olarak analize eklenmiştir. İki opsiyondan daha fazla davranış seçeneği olan vinyetlerde ise ayırdedici fonksiyon analizi kullanılmıştır. Eğer bir davranış opsiyonu 35 katılımcıdan daha az kişi tarafından seçildiyle, bu seçenek düşük örneklem boyutu nedeniyle analizden çıkarılmıştır (Burns ve Burns, 2008). 


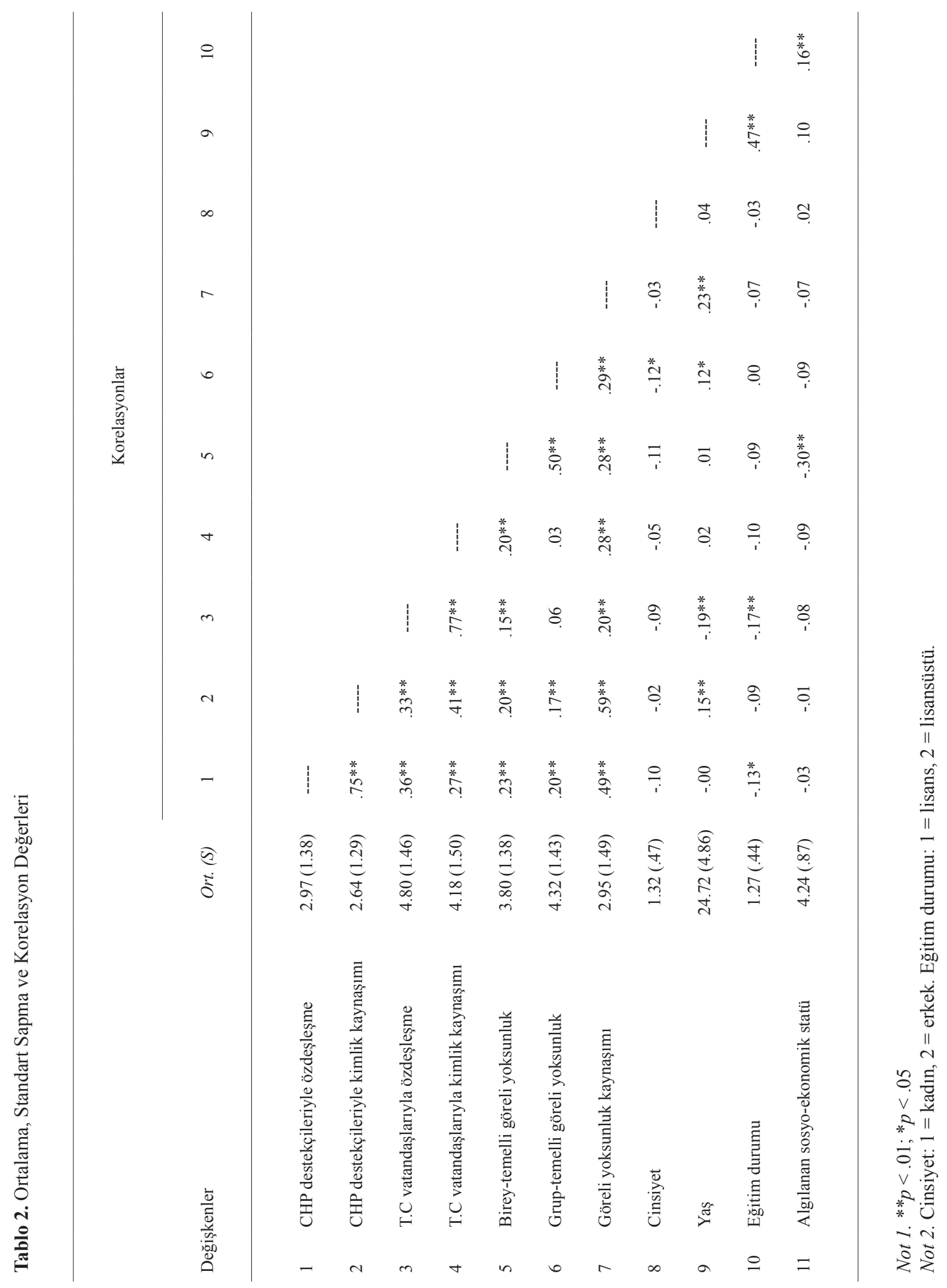


Tablo 3. Vinyetler Yardımıyla CHP Destekçilerinin Aşırı Fedakâr Grup-yanlısı Davranışlarını Yordama

\begin{tabular}{|c|c|c|c|c|c|c|}
\hline \multirow[b]{2}{*}{ Değişkenler } & \multicolumn{6}{|c|}{ Vinyet 1} \\
\hline & $B$ & $S H B$ & Wald $\chi^{2}$ & $O R$ & $\% 95$ GA OR & Model Özeti \\
\hline 1. CHP destekçileriyle özdeşleşme & -.12 & .13 & .872 & .889 & {$[.694,1.14]$} & \multirow{2}{*}{$\begin{array}{c}\text { Blok: } \chi^{2}(2)=9.94, p=.007 \\
\text { Model: } \chi^{2}(2)=9.94, p=.007 \\
\text { Nagelkerke } R^{2}=.04\end{array}$} \\
\hline 2. CHP destekçileriyle kimlik kaynaşımı & $.36^{* *}$ & .14 & 7.02 & 1.44 & {$[1.10,1.88]$} & \\
\hline 3. T.C vatandaşlarıyla özdeşleşme & -.25 & .14 & 3.47 & .777 & {$[.596,1.01]$} & \multirow{2}{*}{$\begin{array}{c}\text { Blok: } \chi^{2}(2)=13.76, p=.001 ; \\
\text { Model: } \chi^{2}(4)=23.70, p<.001 ; \\
\text { Nagelkerke } R^{2}=.10\end{array}$} \\
\hline 4. T.C vatandaşlarıyla kimlik kaynaşımı & $.46^{* *}$ & .14 & 11.61 & 1.59 & {$[1.22,2.08]$} & \\
\hline 5. Birey-temelli göreli yoksunluk & .09 & .10 & .821 & 1.10 & {$[.898,1.34]$} & \multirow{2}{*}{$\begin{array}{c}\text { Blok: } \chi^{2}(2)=1.44, p=.486 ; \\
\text { Model: } \chi^{2}(6)=25.15, p<.001 ; \\
\text { Nagelkerke } R^{2}=.10\end{array}$} \\
\hline 6. Grup-temelli göreli yoksunluk & -.11 & .10 & 1.27 & .896 & {$[.740,1.08]$} & \\
\hline \multirow[t]{3}{*}{ 7. Göreli yoksunluk kaynaşımı } & $.37 * *$ & .11 & 12.23 & 1.44 & {$[1.18,1.77]$} & $\begin{array}{c}\text { Blok: } \chi^{2}(1)=12.78, p<.001 \\
\text { Model: } \chi^{2}(7)=37.93, p<.001 ; \\
\text { Nagelkerke } R^{2}=.15\end{array}$ \\
\hline & \multicolumn{6}{|c|}{ Vinyet 2} \\
\hline & $B$ & $S H B$ & Wald $\chi^{2}$ & $O R$ & $\% 95$ GA OR & Model Özeti \\
\hline 1 & $-.29 *$ & .13 & 5.03 & .749 & {$[.581, .964]$} & \multirow{2}{*}{$\begin{array}{c}\text { Blok: } \chi^{2}(2)=15.97, p<.001 ; \\
\text { Model: } \chi^{2}(2)=15.97, p<.001 ; \\
\text { Nagelkerke } R^{2}=.07\end{array}$} \\
\hline 2 & $.54 * *$ & .15 & 13.99 & 1.72 & {$[1.29,2.28]$} & \\
\hline 3 & .00 & .13 & .000 & 1.00 & {$[.777,1.29]$} & \multirow{2}{*}{$\begin{array}{c}\text { Blok: } \chi^{2}(2)=.217, p=.897 ; \\
\text { Model: } \chi^{2}(4)=16.19, p=.003 ; \\
\text { Nagelkerke } R^{2}=.07\end{array}$} \\
\hline 4 & -.04 & .13 & .100 & .960 & {$[.745,1.24]$} & \\
\hline 5 & -.12 & .10 & 1.34 & .891 & {$[.732,1.08]$} & \multirow{2}{*}{$\begin{array}{c}\text { Blok: } \chi^{2}(2)=1.36, p=.506 ; \\
\text { Model: } \chi^{2}(6)=17.55, p=.007 \\
\text { Nagelkerke } R^{2}=.07\end{array}$} \\
\hline 6 & .04 & .10 & .180 & 1.04 & {$[.865,1.25]$} & \\
\hline 7 & $.24 *$ & .10 & 5.44 & 1.27 & {$[1.04,1.55]$} & $\begin{array}{c}\text { Blok: } \chi^{2}(1)=5.56, p=.018 ; \\
\text { Model: } \chi^{2}(7)=23.11, p=.002 ; \\
\text { Nagelkerke } R^{2}=.09\end{array}$ \\
\hline
\end{tabular}

Vinyet 3

Fonksiyonlarla Yordanan Değişkenlerin

Korelasyonları

Değişkenler

Fonksiyon $1 \quad$ Fonksiyon 2

Fonksiyon 1

Fonksiyon 2

\begin{tabular}{|c|c|c|c|c|c|}
\hline 1 & -.01 & -.54 & Kanonik $R^{2}$ & .18 & .02 \\
\hline 2 & .26 & -.39 & & & \\
\hline 3 & $.46^{*}$ & .03 & Özdeğer & .21 & .02 \\
\hline 4 & $.78^{*}$ & -.04 & & & \\
\hline 5 & .00 & .38 & Wilks' $\lambda$ & .806 & .979 \\
\hline 6 & -.15 & .65 & & & \\
\hline 7 & $.49^{*}$ & -.03 & $\chi^{2}$ & $67.54 * *$ & 6.55 \\
\hline
\end{tabular}


Tablo 3. Vinyetler Yardımıyla CHP Destekçilerinin Aşıı Fedakâr Grup-yanlısı Davranışlarını Yordama

\begin{tabular}{|c|c|c|c|c|c|c|}
\hline \multirow[b]{2}{*}{ Değişkenler } & \multicolumn{6}{|c|}{ Vinyet 4} \\
\hline & $B$ & $S H B$ & Wald $\chi^{2}$ & $O R$ & $\% 95$ GA OR & Model Özeti \\
\hline 1 & -.08 & .13 & .399 & .924 & {$[.722,1.18]$} & \multirow{2}{*}{$\begin{array}{c}\text { Blok: } \chi^{2}(2)=1.77, p=.413 ; \\
\text { Model: } \chi^{2}(2)=1.77, p=.413 \\
\text { Nagelkerke } R^{2}=.01\end{array}$} \\
\hline 2 & .17 & .14 & 1.55 & 1.18 & {$[.908,1.54]$} & \\
\hline 3 & -.17 & .14 & 1.51 & .847 & {$[.650,1.10]$} & \multirow{2}{*}{$\begin{array}{c}\text { Blok: } \chi^{2}(2)=17.80, p<.001 \\
\text { Model: } \chi^{2}(4)=19.57, p=.001 ; \\
\text { Nagelkerke } R^{2}=.08\end{array}$} \\
\hline 4 & $.47^{* *}$ & .14 & 12.09 & 1.61 & {$[1.23,2.10]$} & \\
\hline 5 & .11 & .10 & 1.22 & 1.12 & {$[.916,1.37]$} & \multirow{2}{*}{$\begin{array}{c}\text { Blok: } \chi^{2}(2)=1.23, p=.541 ; \\
\text { Model: } \chi^{2}(6)=20.80, p=.002 ; \\
\text { Nagelkerke } R^{2}=.09\end{array}$} \\
\hline 6 & -.05 & .10 & .274 & .950 & {$[.784,1.15]$} & \\
\hline \multirow[t]{2}{*}{7} & $.40 * *$ & .11 & 13.91 & 1.49 & {$[1.21,1.84]$} & $\begin{array}{c}\text { Blok: } \chi^{2}(1)=14.79, p<.001 ; \\
\text { Model: } \chi^{2}(7)=35.58, p<.001 ; \\
\text { Nagelkerke } R^{2}=.14\end{array}$ \\
\hline & \multicolumn{6}{|c|}{ Vinyet 5} \\
\hline Değişkenler & $B$ & $S H B$ & Wald $\chi^{2}$ & $O R$ & $\% 95 G A O R$ & Model Özeti \\
\hline 1 & -.10 & .13 & .657 & .902 & {$[.702,1.16]$} & \multirow{2}{*}{$\begin{array}{c}\text { Blok: } \chi^{2}(2)=1.56, p=.458 \\
\text { Model: } \chi^{2}(2)=1.56, p=.458 \\
\text { Nagelkerke } R^{2}=.01\end{array}$} \\
\hline 2 & .17 & .14 & 1.52 & 1.18 & {$[.905,1.55]$} & \\
\hline 3 & -.07 & .14 & .233 & .963 & {$[.715,1.23]$} & \multirow{2}{*}{$\begin{array}{c}\text { Blok: } \chi^{2}(2)=25.17, p<.001 ; \\
\text { Model: } \chi^{2}(4)=26.74, p<.001 ; \\
\text { Nagelkerke } R^{2}=.11\end{array}$} \\
\hline 4 & $.50 * *$ & .14 & 12.81 & 1.64 & {$[1.25,2.16]$} & \\
\hline 5 & .16 & .11 & 2.23 & 1.17 & {$[.952,1.44]$} & \multirow{2}{*}{$\begin{array}{c}\text { Blok: } \chi^{2}(2)=2.33, p=.312 ; \\
\text { Model: } \chi^{2}(6)=29.07, p<.001 ; \\
\text { Nagelkerke } R^{2}=.12\end{array}$} \\
\hline 6 & -.05 & .10 & .226 & .953 & {$[.780,1.16]$} & \\
\hline \multirow[t]{2}{*}{7} & $.35^{* *}$ & .11 & 10.47 & 1.42 & {$[1.15,1.75]$} & $\begin{array}{c}\text { Blok: } \chi^{2}(1)=10.95, p=.001 ; \\
\text { Model: } \chi^{2}(7)=40.01, p<.001 ; \\
\text { Nagelkerke } R^{2}=.16\end{array}$ \\
\hline & \multicolumn{6}{|c|}{ Vinyet 6} \\
\hline Değişkenler & $B$ & $S H B$ & Wald $\chi^{2}$ & OR & $\% 95 G A O R$ & Model Özeti \\
\hline 1 & -.10 & .13 & .577 & .908 & {$[.709,1.16]$} & \multirow{2}{*}{$\begin{array}{c}\text { Blok: } \chi^{2}(2)=1.56, p=.459 \\
\text { Model: } \chi^{2}(2)=1.56, p=.459 \\
\text { Nagelkerke } R^{2}=.01\end{array}$} \\
\hline 2 & .17 & .14 & 1.49 & 1.18 & {$[.905,1.54]$} & \\
\hline 3 & -.12 & .14 & .791 & .886 & {$[.679,1.16]$} & \multirow{2}{*}{$\begin{array}{c}\text { Blok: } \chi^{2}(2)=21.58, p<.001 ; \\
\text { Model: } \chi^{2}(4)=23.14, p<.001 ; \\
\text { Nagelkerke } R^{2}=.10\end{array}$} \\
\hline 4 & $.49^{* *}$ & .14 & 12.69 & 1.63 & {$[1.25,2.13]$} & \\
\hline 5 & .13 & .10 & 1.48 & 1.13 & {$[.926,1.39]$} & \multirow{2}{*}{$\begin{array}{c}\text { Blok: } \chi^{2}(2)=1.50, p=.473 ; \\
\text { Model: } \chi^{2}(6)=24.63, p<.001 ; \\
\text { Nagelkerke } R^{2}=.10\end{array}$} \\
\hline 6 & -.07 & .10 & .438 & .936 & {$[.771,1.14]$} & \\
\hline 7 & $.48^{* *}$ & .11 & 18.80 & 1.62 & {$[1.30,2.01]$} & $\begin{array}{c}\text { Blok: } \chi^{2}(1)=20.56, p<.001 ; \\
\text { Model: } \chi^{2}(7)=45.19, p<.001 ; \\
\text { Nagelkerke } R^{2}=.18\end{array}$ \\
\hline
\end{tabular}




\section{Vinyet 1}

İlk vinyette beş yerel iç-grup üyesinin tehlikede olduğu vurgulanarak katılımcıların sosyal kimliği aktive edilmiş ve kişilerden "hiçbir şey yapmama ve beş CHPli'nin ölümüne izin verme" ya da "beş CHPli'nin hayatını kurtarmak için kendi hayatını feda etme" davranış opsiyonlarından birini seçmeleri beklenmiştir (bkz. Tablo 1; Tablo 3).

CHPliler'le özdeşleşme ve kimlik kaynaşımı değişkenlerini içeren ilk blok anlamlı bulunmuş $\chi^{2}(2)=9.94$, $p=.007$ ve aşırı fedakâr davranış sergileme eğiliminin \%4'ünü açıklamıştır. CHP destekçileriyle kimlik kaynaşımı beş CHPli'nin hayatını kurtarmak için kendi hayatını feda etme opsiyonunu seçme olasılığını 1.44 kez artırmıştır, $B=.36 ; S H=.14 ;$ Wald $\chi^{2}(1)=7.02, p=.008, \mathrm{OR}=$ $1.44, \% 95$ GA OR $[1.10,1.88]$. T.C vatandaşlarıyla özdeşleşme ve kimlik kaynaşımı değişkenlerinin denkleme eklendiği ikinci model anlamlıdır $\chi^{2}(4)=23.70, p<.001$ ve aşırı fedakâr davranış sergileme eğiliminin \%10'unu açıklamıştır. T.C vatandaşlarıyla kimlik kaynaşımı beş CHPli'nin hayatını kurtarmak için kendi hayatını feda etme opsiyonunu seçme olasılığını $1.59 \mathrm{kez}$ artırmıştır, $B$ $=.46 ; \mathrm{SH}=.14 ;$ Wald $\chi^{2}(1)=11.61, p=.001, \mathrm{OR}=1.59$, \%95 GA OR $[1.22,2.08]$. Üçüncü modelde ise birey-temelli ve grup-temelli yoksunluk değişkenleri denkleme eklenmiștir. Model anlamlı olsa da $\chi^{2}(6)=25.15, p<.001$, test edilen değişkenler anlamlı ilişki göstermemiştir. Son adımda ise göreli yoksunluk kaynaşımı değişkeni modele eklenmiştir. Model anlamlı bulunmuş $\chi^{2}(7)=37.93, p<$ .001 , varyansın \%15'ini açıklamıştır. Göreli yoksunluk kaynaşımı beș CHPli'nin hayatını kurtarmak için kendi hayatını feda etme opsiyonunu seçme olasılığını $1.44 \mathrm{kez}$ artırmıştır, $B=.37 ; S H=.11 ;$ Wald $\chi^{2}(1)=12.23, p<.001$, $\mathrm{OR}=1.44, \% 95$ GA OR $[1.18,1.77]$.

\section{Vinyet 2}

İkinci vinyette kişinin kendisinin tehlikede olduğu vurgulanarak bireysel kimlik aktive edilmiş ve kişilerden "kendi hayatını kurtarmak için beş CHPli'nin ölümüne neden olma" ya da "kendi hayatını feda etme" davranış opsiyonlarından birini seçmeleri beklenmiştir (bkz. Tablo 1; Tablo 3).

İlk blok anlamlı bulunmuş $\chi^{2}(2)=15.97, p<.001$ ve varyansın \%7'sini açıklamıştır. CHP destekçileriyle özdeşleşme kendi hayatını feda etme opsiyonunu seçme olasılığını .749 kez azaltmıştır, $B=-.29 ; S H=.13$; Wald $\chi^{2}(1)=5.03, p=.025$, OR $=.749, \% 95$ GA OR [.581, .964]. CHP destekçileriyle kimlik kaynaşımı ise kendi hayatını feda etme opsiyonunu seçme olasılığını $1.72 \mathrm{kez}$ artırmıştır, $B=.54 ; S H=.15$; Wald $\chi^{2}(1)=13.99, p<.001$, $\mathrm{OR}=1.72, \% 95$ GA OR $[1.29,2.28]$. İkinci ve üçüncü modeller anlamlı bulunmuştur $\chi^{2}(4)=16.19, p=.003$; $\chi^{2}(6)=17.55, p=.007$, ancak test edilen değişkenler aşırı fedakâr davranış sergileme eğilimini yordamamıştır. Son model ise anlamlıdir $\chi^{2}(7)=23.11, p=.002$ ve varyansin \%9'unu açıklamıştır. Göreli yoksunluk kaynaşımı kendi hayatını feda etme opsiyonunu seçme olasılığını $1.27 \mathrm{kez}$ artırmıştır, $B=.24 ; S H=.10 ;$ Wald $\chi^{2}(1)=5.44, p=.020$, $\mathrm{OR}=1.27, \% 95$ GA OR $[1.04,1.55]$.

\section{Vinyet 3}

Üçüncü vinyette beş geniş iç-grup üyesinin yaşamına karşı bir yerel iç-grup üyesinin yaşamı ikilemi ve kişinin aşırı fedakâr davranış sergileme eğilimi test edilmiştir. Katılımcılardan "hiçbir şey yapmama ve beş T.C vatandaşının ölümüne izin verme", "beş T.C vatandaşının hayatını kurtarmak için kendi hayatını feda etme" ya da "bir CHPli'nin ölümüne neden olma ve beş T.C vatandaşının hayatını kurtarma" seçeneklerinden birini seçmeleri istenmiştir (bkz. Tablo 1; Tablo 3).

Ayırdedici fonksiyon analizi iki fonksiyon hesaplamıştır. İlk fonksiyon anlamlıdır Wilks' $\lambda=.806 ; \chi^{2}(14)=$ $67.54, p<.001$ ve varyansın $\% 18$ 'ini açıklamıştır. İkinci fonksiyon ise anlamlı değildir $\chi^{2}(6)=6.55, p=.365$. İlk fonksiyon "hiçbir şey yapmama ve beş T.C vatandaşının ölümüne izin verme" ve "beş T.C vatandaşının hayatını kurtarmak için kendi hayatını feda etme" seçeneklerini azami ölçüde ayırdetmiştir. T.C vatandaşlarıyla kimlik kaynaşımı, göreli yoksunluk kaynaşımı ve T.C vatandaşlarıyla özdeşleşme değişkenlerinde yüksek skor almış kişiler T.C vatandaşlarının hayatını kurtarmak için kendi hayatını feda etme opsiyonunu tercih eden kişilerdir.

\section{Vinyet 4,5 ve 6}

Dördüncü, beşinci ve altıncı vinyette ise, beş geniş iç-grup üyesinin yaşamına karşı beş yerel dış-grup üyesinin yaşamı (AKP, HDP ve MHP destekçileri s1rasıyla vinyet 4, 5 ve 6'da yerel diş-grup üyesi olarak belirtilmiştir) ikilemi ve kişinin aşırı fedakâr davranış sergileme eğilimi incelenmiştir. Katılımcılar "hiçbir şey yapmama ve beş T.C vatandaşının ve beş AKPli'nin / beş HDPli'nin / beş MHPli'nin ölümüne izin verme", "beş T.C vatandaşının hayatını kurtarmak için kendi hayatını feda etme ve beş AKPli'nin / beş HDPli'nin / beş MHPli'nin ölümüne izin verme" ya da "beş AKPli'nin / beş HDPli'nin / beş MHPli'nin hayatını kurtarmak için kendi hayatını feda etme ve beş T.C vatandaşının ölümüne izin verme" seçeneklerinden birini tercih etmiştir (bkz. Tablo 1; Tablo 3).

Üç vinyette de çok az sayıda katılımcı yerel dışgrup üyelerinin hayatını kurtarmak için kendi hayatını feda etme seçeneğini tercih ettiğinden ötürü bu seçenek analizlerden çıkarılmıştır. Ek olarak, üç vinyet bulgularında da benzer bir anlamlılık örüntüsü görülmüştür. CHP destekçileriyle özdeșleşme ve kimlik kaynaşımı değişkenlerinin test edildiği ilk bloklar 4,5 ve 6 numaralı 
vinyetlerde anlamlı değildir $\chi^{2}(2)=1.77, p=.413 ; \chi^{2}(2)$ $=1.56, p=.458 ; \chi^{2}(2)=1.56, p=.459$.

T.C vatandaşlarıyla özdeşleşme ve kimlik kaynaŞımı ikinci modellerde denkleme dâhil edilmiştir. Dördüncü vinyette belirtilen ikinci model anlamlı bulunmuş $\chi^{2}(4)=19.57, p=.001$ ve varyansın \%8'ini açıklamıştır. T.C vatandaşlarıyla kimlik kaynaşımı beş T.C vatandaşını kurtarmak için kendi hayatını feda etme ve beş AKPli'nin ölümüne izin verme opsiyonunu seçme olas1lığını $1.61 \mathrm{kez}$ artırmıştır; $B=.47 ; S H=.14 ;$ Wald $\chi^{2}(1)$ $=12.09, p=.001, \mathrm{OR}=1.61, \% 95$ GA OR $[1.23,2.10]$. Beşinci vinyette de belirtilen ikinci model anlamlıdır $\chi^{2}(4)=26.74, p<.001$ ve varyansın \%11'ini açıklamıştır. T.C vatandaşlarıyla kimlik kaynaşımı beş T.C vatandaşını kurtarmak için kendi hayatını feda etme ve beş HDPli'nin ölümüne izin verme opsiyonunu seçme olas1lığını 1.64 kez artırmıştır; $B=.50 ; S H=.14 ;$ Wald $\chi^{2}(1)$ $=12.81, p<.001, \mathrm{OR}=1.64, \% 95$ GA OR $[1.25,2.16]$. Altıncı vinyette de belirtilen model anlamlı bulunmuştur $\chi^{2}(4)=23.14, p<.001$ ve varyansın \%10'unu açıklamıştır. T.C vatandaşlarıyla kimlik kaynaşımı beş T.C vatandaşını kurtarmak için kendi hayatını feda etme ve beş MHPli'nin ölümüne izin verme opsiyonunu seçme olas1lığını 1.63 kez artırmıştır; $B=.49 ; S H=.14 ;$ Wald $\chi^{2}(1)$ $=12.69, p<.001, \mathrm{OR}=1.63, \% 95$ GA OR $[1.25,2.13]$.

Üçüncü blokta birey-temelli ve grup-temelli yoksunluklar denkleme eklenmiştir. Üçüncü modeller 4, 5 ve 6 numaral 1 vinyetlerde anlamlidir $\chi^{2}(6)=20.80, p=$ $.002 ; \chi^{2}(6)=29.07, p<.001 ; \chi^{2}(6)=24.63, p<.001$, ancak test edilen değişkenler aşırı fedakâr davranış sergileme eğilimiyle anlamlı ilişki göstermemiștir.

Göreli yoksunluk kaynaşımı dördüncü bloklarda denkleme eklenmiştir. Dördüncü vinyette test edilen dördüncü model anlamlı bulunmuş $\chi^{2}(7)=35.58, p<$ .001 ve varyansın \%14'ünü açıklamıştır. Göreli yoksunluk kaynaşımı beş T.C vatandaşını kurtarmak için kendi hayatını feda etme ve beş AKPli'nin ölümüne izin verme opsiyonunu seçme olasılığını $1.49 \mathrm{kez}$ artırmıştır; $B=$ $.40 ; S H=.11 ;$ Wald $\chi^{2}(1)=13.91, p<.001, \mathrm{OR}=1.49$, $\% 95$ GA OR $[1.21,1.84]$. Beşinci vinyette de belirtilen dördüncü model anlamlıdır $\chi^{2}(7)=40.01, p<.001$ ve varyansın \%16'sını açıklamıştır. Göreli yoksunluk kaynaşımı beş T.C vatandaşını kurtarmak için kendi hayatını feda etme ve beş HDPli'nin ölümüne izin verme opsiyonunu seçme olasılığını $1.42 \mathrm{kez}$ artırmıştır; $B=.35$; $S H=.11 ;$ Wald $\chi^{2}(1)=10.47, p=.001, \mathrm{OR}=1.42, \% 95$ GA OR $[1.15,1.75]$. Altınc1 vinyette ise belirtilen model anlamlıdır $\chi^{2}(7)=45.19, p<.001$ ve varyansın $\% 18$ 'ini açıklamıştır. Göreli yoksunluk kaynaşımı beş T.C vatandaşını kurtarmak için kendi hayatını feda etme ve beş MHPli'nin ölümüne izin verme opsiyonunu seçme olas1lı̆̆ını $1.62 \mathrm{kez}$ artırmıștır; $B=.48 ; S H=.11 ;$ Wald $\chi^{2}(1)$ $=18.80, p<.001, \mathrm{OR}=1.62, \% 95$ GA OR $[1.30,2.01]$.

\section{Tartışma}

$\mathrm{Bu}$ çalışma kimlik-temelli ve yoksunluk-temelli kuramlardan faydalanarak, iç-grup üyelerini korumak için kendi hayatını feda etme gibi kişinin aşırı fedakâr grup-yanlısı davranış sergileme eğilimini araştırmaktadır. Siyasi kimliğini CHP olarak tanımlayan kişilerin katıldığı çalışmada yerel iç-grup (CHP destekçileri), geniş iç-grup (T.C vatandaşları) ve yerel diş-gruplarla (AKP, HDP ve MHP destekçileri) ilişkiler farklı gruplar arası durumları içeren vinyetler kullanılarak incelenmiștir.

Çalışmanın vurguladığı "birey ve grup seviyelerinde gerçekleşen süreçlerin (bireysel kimlik ve sosyal kimlik; birey-temelli yoksunluk ve grup-temelli yoksunluk) aynı anda etkin ve birbiri ile ilişkili olabileceği ve yine bu süreçlerin birbirini destekleyerek aşırı grup-yanlısı davranış sergileme motivasyonunu kuvvetlendirebileceği” görüşü ve hipotezler, araştırmanın analiz bulgularıyla desteklenmiştir (bkz. Tablo 2; Tablo 3; Tablo 4). CHP destekçileriyle ve T.C vatandaşlarıyla kimlik kaynaşımları sırasıyla, CHP destekçilerini ve T.C vatandaşlarını korumak amacıyla aşırı fedakâr davranış sergileme eğilimlerini pozitif olarak yordamıştır. Bu gruplarla özdeşleşme değişkenleri ise aşırı fedakâr davranış sergileme eğilimlerini yordamada yetersiz kalmıştır (Hipotez 1). Göreli yoksunluk kaynaşımı ise CHP destekçileri ve T.C vatandaşlarını korumak amacıyla aşırı fedakâr davranış sergileme eğilimlerini pozitif olarak yordarken, ayrı seviyelerdeki birey-temelli ve grup-temelli göreli yoksunluk halleri aşırı fedakâr davranış sergileme eğilimlerini açıklayamamıștır (Hipotez 2).

Araştırma bulguları, aşırı fedakâr grup-yanlısı davranışları açıklayan kuramsal bir çerçeve sunmaktadır. Grup-yanlısı davranışlar alanyazında çeşitli yaklaşımlarla çalışılmış, ancak grup üyeleri uğruna kendi hayatını feda etmek gibi aşırı grup-yanlısı davranışların altında yatan motivasyon henüz netleşmemiştir. Grup-yanlısı davranışları açıklamak için sıklıkla kullanılan iç-grup özdeşleşmesi kavramı ve Sosyal Kimlik Kuramı (Tajfel ve Turner, 1979), bu araştırmada beklendiği üzere aşırı grup-yanlısı davranış sergileme eğilimini yordayamamıştır. Bu bulgu grup-yanlısı davranış alanyazınının yeni yaklaşımlara ihtiyaç duyduğunu göstermektedir. Kimlik Kaynaşımı Kuramı (örn. Swann ve ark., 2009; 2012) Sosyal Kimlik Kuramı'nın eksik yönlerini tamamlayan görece yeni bir yaklaşımdır ve Türkiye'de henüz çal1şılmamıştır.

Göreli Yoksunluk Kuramı (örn. Davis, 1959; Gurr, 1970; Runciman, 1966) ise grup-temelli davranışları gruplar arası karşılaştırmalar ve grup-temelli yoksunluk haliyle açıklamaktadır (örn. Smith ve ark., 2012; Walker ve Mann, 1987). Fakat bu çalışmanın bulguları göstermiştir ki birey ve grup seviyesindeki yoksunluk halle- 
Tablo 4. Vinyetlerde Gözlemlenen Anlamlı İlişkilerin Özeti

\begin{tabular}{|c|c|c|c|c|c|c|}
\hline Değisskenler & Vinyet 1 & Vinyet 2 & Vinyet 3 & Vinyet 4 & Vinyet 5 & Vinyet 6 \\
\hline
\end{tabular}

CHP destekçileriyle özdeşleşme

CHP destekçileriyle kimlik kaynaşımı

T.C vatandaşlarıyla özdeşleşme

T.C vatandașlarıyla kimlik kaynaşımı

Birey-temelli göreli yoksunluk

Grup-temelli göreli yoksunluk

Göreli yoksunluk kaynaşımı

$+* * \quad+* *$

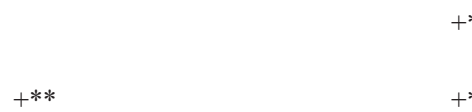

$+*$
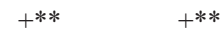

$+* *$

$+*$

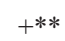

$+* *$

Not. $* * p<.01 ; * p<.05$.

rinin örtüşmesi (kaynaşımı) aşırı grup-yanlısı davranışları güçlü bir şekilde pozitif olarak yordamaktadır. Bir başka ifadeyle, aynı anda etkin ve birbiriyle ilişsili birey-temelli ve grup-temelli yoksunluk hali aşırı fedakâr grup-yanlısı davranış sergileme eğilimini artırmaktadır. $\mathrm{Bu}$ bulgu grup-temelli yoksunluk halinin yanı sıra, birey-temelli yoksunluk halinin de grup-yanlısı davranışlarla ilişkili olabileceğini destekler niteliktedir.

Araştırmanın bulguları değerlendirilirken çalışmanın kısıtlılıkları göz önünde bulundurulmalıdır. Çalışmanın korelasyon-temelli deseni ve analiz yöntemleri, nedensel ilişkilere dayanan çıkarımlar yapılmasını engellemektedir. Bu sebeple okuyucu, sunulan bulgular 1şığında nedensel ilişki yargılarından kaçınmalıdır. İkinci olarak, mevcut çalışmanın verisi sadece CHP destekçilerini kapsamaktadır. İleride yapılacak çalışmalar farklı siyasi kimliklere sahip kişileri içermeli ve bulguların geçerlik ve güvenirliği farklı örneklemlerle test edilmelidir. Son olarak, Türkiye'nin hareketli sosyo-politik gündemini dikkate almak gerekmektedir. Veri toplama sürecinde ulusal ve uluslararası seviyelerde yaşanan pek çok olumsuz durum (örn. askeri darbe girişimi, olağanüstü hal, terör eylemleri, Suriyeli mülteci krizi, diğer ülkelerle gerilen ilişkiler, vb.) Türkiye'nin gündemini meşgul etmiştir. Böylesine hareketli bir dönemde bazı kişiler siyasi parti isimleri geçen bir çalışmaya katılmak istememiş ve verdikleri yanıtların farklı amaçlar için kullanılmasından endişe duymuştur. Veri kirliliğini önlemek amacıyla önemli gelişmelerin olduğu zamanlarda veri toplama sürecine ara verilmiş ve siyasi ortamın görece durgunlaşması beklenmiştir. Bu sebeple araştırma verisi 11 ay gibi görece uzun bir sürede toplanabilmiştir.

Özetle, araştırma az çalışılan ancak terörist eylemleri dahi açıklayabilecek bir husus olan, aşırı fedakâr grup-yanlısı davranış (grup üyelerini korumak için kendi hayatını feda etmek) sergileme eğilimi gibi önemli bir konuya odaklanmaktadır. Ek olarak, birey ve grup seviyelerinde gerçekleşen süreçlerin eş zamanlı etkin, birbiriyle örtüşmüş (kaynaşmış) ve birbirini destekleyen süreçler olabileceğini ve aşırı grup-yanlısı davranışları açıklayabileceğini önermektedir. Araştırma konusu, katılımcı örneklemi, test edilen yeni kuramsal yaklaşımlar ve tutarlı bulgular dikkate alındığında mevcut araştırma ulusal ve uluslararası düzeyde önemlidir. 


\section{Kaynaklar}

Abrams, D., \& Grant, P. R. (2012). Testing the social identity relative deprivation (SIRD) model of social change: The political rise of Scottish nationalism. British Journal of Social Psychology, 51, 674-689. doi: 10.1111/j.2044-8309.2011.02032.x

Buhrmester, M. D., Gomez, A., Brooks, M. L., Morales, J. F., Fernandez, S., \& Swann, W. B. Jr. (2012). My group's fate is my fate: Identity-fused Americans and Spaniards link personal life quality to outcome of 2008 elections. Basic and Applied Social Psychology, 34, 527-533. doi: 10.1080/01973533.2012.732825

Burns, R. B., \& Burns, R. A. (2008). Business research methods and statistics using SPSS. London: Sage.

Crosby, F. (1976). A model of egoistical relative deprivation. Psychological Review, 83, 85-113. doi: 10.1037/0033-295X.83.2.85

Davis, J. A. (1959). A formal interpretation of the theory of relative deprivation. Sociometry, 22, 280-296. doi: $10.2307 / 2786046$

Foster, M. D., \& Matheson, K. (1995). Double relative deprivation: Combining the personal and political. Personality and Social Psychology Bulletin, 21(11), 1167-1177. doi: 10.1177/01461672952111005

Gomez, A., Brooks, M. L., Buhrmester, M. D., Vazquez, A., Jetten, J., \& Swann, W. B. Jr. (2011). On the nature of identity fusion: Insights into the construct and a new measure. Journal of Personality and Social Psychology, 100(5), 918-933. doi: 10.1037/ a0022642

Gomez, A., Lopez-Rodriguez, L., Sheikh, H., Ginges, J., Wilson, L., Waziri, H., ... \& Atran, S. (2017). The devoted actor's will to fight and the spiritual dimension of human conflict. Nature Human Behaviour, 1, 673-679. doi: 10.1038/s41562-017-0193-3

Gurr, T. R. (1970). Why men rebel. Princeton, NJ: Princeton University Press.

Hogg, M. A. (1987). Social identity and group cohesiveness. J. C. Turner (Ed.), Rediscovering the social group içinde (89-116). New York: Basil Blackwell.

Hogg, M. A. (1993). Group cohesiveness: A critical review and some new directions. European Review of Social Psychology, 4, 85-111. doi: 10.1080/14792779343000031

Hogg, M. A., \& Hardie, E. A. (1991). Social attraction, personal attraction, and self-categorization: A field study. Personality and Social Psychology Bulletin, 17, 175-180. doi: 10.1177/014616729101700209

Levine, M., \& Crowther, S. (2008). The responsive bystander: How social group membership and group size can encourage as well as inhibit bystander in- tervention. Journal of Personality and Social Psychology, 95, 1429-1439. doi: 10.1037/a0012634

Mael, F. A., \& Ashforth, B. E. (1992). Alumni and their alma mater: A partial test of the reformulated model of organizational identification. Journal of $\mathrm{Or}$ ganizational Behavior, 13, 103-123. doi: 10.1002/ job.4030130202

Osborne, D., \& Sibley, C. G. (2013). Through rose-colored glasses: System-justifying beliefs dampen the effects of relative deprivation on well-being and political mobilization. Personality and Social Psychology Bulletin, 39(8), 991-1004. doi: 10.1177/0146167213487997

Özdemir, F. (2018). The fusion of individual and group levels: The case of political party supporters within extreme pro-group action process. Orta Doğu Teknik Üniversitesi, Ankara, Türkiye: Basılmamış Doktora Tezi.

Özdemir, F., Tekeş, B., \& Öner-Özkan, B. (2019). Birey düzeyinde göreli yoksunluk ve öznel esenlik arasındaki dolaylı ilişki. Türk Psikoloji Dergisi, 34(84), 37-53. doi: 10.31828/ tpd1300443320180811m000009

Pettigrew, T. F., Christ, O., Wagner, U., Meertens, R. W., van Dick, R., \& Zick, A. (2008). Relative deprivation and intergroup prejudice. Journal of Social Issues, 64, 385-401. doi: 10.1111/j.15404560.2008.00567.x

Runciman, W. G. (1966). Relative deprivation and social justice: A study of attitudes to social inequality in twentieth-century England. Berkeley: University of California Press.

Smith, H. J., \& Ortiz, D. J. (2002). Is it just me? I. Walker ve H. Smith (Ed.), Relative deprivation içinde (91-115). Cambridge: Cambridge University Press.

Smith, H. J., Pettigrew, T. F., Pippin, G. M., \& Bialosiewicz, S. (2012). Relative deprivation: A theoretical and meta-analytic review. Personality and Social Psychology Review, 16(3), 203-232. doi: 10.1177/1088868311430825

Stets, J. E., \& Burke, P. J. (2000). Identity theory and social identity theory. Social Psychology Quarterly, 63(3), 224-237. doi: 10.2307/2695870

Swann, W. B. Jr., \& Buhrmester, M. D. (2015). Identity fusion. Current Directions in Psychological Science, 24(1), 52-57. doi: 10.1177/0963721414551363

Swann, W. B. Jr., Buhrmester, M. D., Gomez, A., Jetten, J., Bastian, B., Vazquez, A., ... \& Zhang, A. (2014). What makes a group worth dying for? Identity fusion fosters perception of familial ties, promoting self-sacrifice. Journal of Personality and Social Psychology, 106(6), 912-926. doi: 10.1037/ a0036089 
Swann, W. B. Jr., Gomez, A., Buhrmester, M. D., Rodriguez, L. L., Jimenez, J., \& Vazquez, A. (2014). Contemplating the ultimate sacrifice: Identity fusion channels pro-group affect, cognition, and moral decision making. Journal of Personality and Social Psychology, 106(5), 713-727. doi: 10.1037/ a0035809

Swann, W. B. Jr., Gomez, A., Dovidio, J. F., Hart, S., \& Jetten, J. (2010). Dying and killing for one's group: Identity fusion moderates responses to intergroup versions of the trolley problem. Psychological Science, 21, 1176-1183. doi: 10.1177/0956797610376656

Swann, W. B. Jr., Gomez, A., Huici, C., Morales, J. F., \& Hixon, J. G. (2010). Identity fusion and self-sacrifice: Arousal as a catalyst of pro-group fighting, dying, and helping behavior. Journal of Personality and Social Psychology, 99(5), 824-841. doi: 10.1037/a0020014

Swann, W. B. Jr., Gomez, A., Seyle, D. C., Morales, J. F., \& Huici, C. (2009). Identity fusion: The interplay of personal and social identities in extreme group behavior. Journal of Personality and Social Psychology, 96(5), 995-1011. doi: 10.1037/a0013668

Swann, W. B. Jr., Jetten, J., Gomez, A., Whitehouse, H., \& Bastian, B. (2012). When group membership gets personal: A theory of identity fusion. Psychological Review, 119(3), 441-456. doi: 10.1037/ a0028589

Swann, W. B. Jr., Wenzlaff, R. M., \& Tafarodi, R. W. (1992). Depression and the search for negative evaluations: More evidence of the role of self-verification strivings. Journal of Abnormal Psychology, 101, 314-317. doi: 10.1037/0021-843X.101.2.314

Tajfel, H., \& Turner, J. C. (1979). An integrative theory of intergroup conflict. W. G. Austin ve S. Worchel (Ed.), The social psychology of intergroup relations içinde (33-47). Monterey, CA: Brooks-Cole.

Taylor, D. M., Moghaddam, F. M., Gamble, I., \& Zellerer, E. (1987). Disadvantaged group responses to perceived inequality: From passive acceptance to collective action. Journal of Social Psychology, 127, 259-272. doi: 10.1080/00224545.1987.9713692

Taylor, D. M., Wright, S. C., Moghaddam, F. M., \& Lalonde, R. N. (1990). The personal/group discrimination discrepancy: Perceiving my group, but not myself, to be a target for discrimination. Personality and Social Psychology Bulletin, 16, 254-263. doi: 10.1177/0146167290162006

Tougas, F., \& Beaton, A. M. (2002). Personal and group relative deprivation: Connecting the "I" to the "we". I. Walker ve H. J. Smith (Ed.), Relative deprivation: Specification, development and integrati- on içinde (119-135). Cambridge, UK: Cambridge University.

Walker, I. (1999). Effects of personal and group relative deprivation on personal and collective self-esteem. Group Processes and Intergroup Relations, 2(4), 365-380. doi: 10.1177/1368430299024004

Walker, I., \& Mann, L. (1987). Unemployment, relative deprivation, and social protest. Personality and Social Psychology Bulletin, 13, 275-283. doi: 10.1177/0146167287132012

Walker, I., \& Pettigrew, T. F. (1984). Relative deprivation theory: An overview and conceptual critique. British Journal of Social Psychology, 23, 301-310. doi: 10.1111/j.2044-8309.1984.tb00645.x 
Ek-1. Araştırma Ölçekleri

Grup Özdeşleşmesi Ölçümü

- $\quad$ Birisi CHPliler'i / T.C vatandaşlarını eleştirdiğinde, şahsıma hakaret edilmiş gibi hissederim.

- Diğer siyasi partilerin üyelerinin CHPliler hakkında / diğer milletlerin T.C vatandaşları hakkında ne düşündüğüyle çok ilgiliyim*

- CHPliler'den / T.C vatandaşlarından bahsederken genellikle "onlar” yerine "biz" diye bahsederim.

- CHPliler'in / T.C vatandaşlarının başarıları benim de başarımdır.

- $\quad$ Birisi CHPliler'i / T.C vatandaşlarını yücelttiğinde sanki bana övgüde bulunmuş gibi hissederim.

- Medyadaki bir haber CHPliler'in / T.C vatandaşlarının olumsuz taraflarını eleştirdiğinde kendimi mahçup hissederim.

Kimlik Kaynaşımı Ölçeği

- $\quad$ CHPliler / T.C vatandaşları ile bir bütünüm.

- $\quad$ Kendimi CHPliler / T.C vatandaşları ile bütünleşmiş hissediyorum.

- $\quad$ CHPliler / T.C vatandaşları ile derin duygusal bir bağım var.

- $\quad$ CHPliler / T.C vatandaşları demek, ben demektir.

- CHPliler / T.C vatandaşları için, diğer CHPli grup üyelerinin / diğer T.C vatandaşlarının yapacağından daha fazla şey yaparım.

- $\quad$ CHPliler / T.C toplumu sayesinde güçlüyüm.

- CHPliler'i / T.C toplumunu güçlü hale getiriyorum.

Birey-temelli ve Grup-temelli Göreli Yoksunluk Ölçeği

- Kendimi diğer T.C vatandaşları ile karşılaştırdığımda, diğer T.C vatandaşlarının benden daha iyi sosyal ve politik imkânlara sahip olduğunun farkındayım.

- Diğer T.C vatandaşlarının sahip olduğu sosyal ve politik imkânlara sahip olmayı isterim.

- Diğer T.C vatandaşlarının sahip olduğu sosyal ve politik imkânları hak ettiğimi düşünürüm.

- $\quad$ Kendimi diğer T.C vatandaşları ile karşılaştırdığımda, sahip olduğum sosyal ve politik imkânlar beni tatmin etmiyor.

- $\quad$ Sosyal ve politik imkânlar konusunda, diğer T.C vatandaşları benden daha iyi durumda.

- CHPliler'i diğer T.C vatandaşları ile karşılaştırdığımda, diğer T.C vatandaşlarının CHPliler'den daha iyi sosyal ve politik imkânlara sahip olduğunun farkındayım.

- $\quad$ Diğer T.C vatandaşlarının sahip olduğu sosyal ve politik imkânlara CHPliler'in de sahip olmasını isterim.

- Diğer T.C vatandaşlarının sahip olduğu sosyal ve politik imkânları CHPliler'in de hak ettiğini düşünürüm.

- CHPliler'i diğer T.C vatandaşları ile karşılaştırdığımda, CHPliler'in sahip olduğu sosyal ve politik imkânlar beni tatmin etmiyor.

- $\quad$ Sosyal ve politik imkânlar konusunda, diğer T.C vatandaşları CHPliler’den daha iyi durumda.

Göreli Yoksunluk Kaynaşımı Ölçeği

- CHPli grup üyeliğime bağlı grup-temelli yoksunluğum ve birey-temelli yoksunluğum bir bütündür.

- $\quad$ CHPli grup üyeliğime bağlı grup-temelli yoksunluğum ile bütünleşmiş hissediyorum.

- $\quad$ CHPli grup üyeliğime bağlı grup-temelli yoksunluğum ile derin duygusal bir bağım var.

- CHPli grup üyeliğime bağlı grup-temelli yoksunluğum, birey-temelli yoksunluğum ile aynıdır.

- CHPli grup üyeliğime bağlı grup-temelli yoksunluğumu gidermek için, diğer CHPliler’in yapacağından daha fazla şey yaparım.

- $\quad$ CHPli grup üyeliğime bağlı grup-temelli yoksunluğum beni etkilemektedir.

- CHPli grup üyeliğime bağlı grup temelli yoksunluğumu giderdiğimde, birey-temelli yoksunluğumu da gidermiş olacağım.

Not 1. Göreli yoksunluk kaynaşımı ölçek maddelerinden önce katılımcılara göreli yoksunluk, birey-temelli göreli yoksunluk ve gruptemelli göreli yoksunluk kavramlarının tanımları verilmiştir.

Not 2. *Bu madde düşük madde-toplam korelasyon değeri ve düşük iç-tutarlılık katsayısı nedeniyle araştırmaya dahil edilmemiştir. 


\section{Summary \\ The Fusion of Individual-based and Group-based Processes: Predicting Tendency to Exhibit Extreme Self-sacrificing Pro-group Behavior}

\author{
Fatih Özdemir \\ Bursa Uludağ University
}

This study aims to rationalize the tendency to exhibit extreme self-sacrificing behaviors as sacrificing own life for the sake of group members using identity-based and deprivation-based approaches, namely, Social Identity Theory (Tajfel \& Turner, 1979), Identity Fusion Theory (Swann, Gomez, Seyle, Morales, \& Huici, 2009; Swann, Jetten, Gomez, Whitehouse, \& Bastian, 2012), and Relative Deprivation Theory (e.g., Crosby, 1976; Davis, 1959; Gurr, 1970; Runciman, 1966). In accordance to this purpose, the study conducted in a sample of people who identify themselves as Republican People's Party (Cumhuriyet Halk Partisi, CHP) supporters, and examined the participants' relationships with other CHP supporters (local in-group), citizens of the Republic of Turkey (extended in-group) and Justice and Development Party (Adalet ve Kalkınma Partisi, AKP) supporters, Peoples' Democratic Party (Halkların Demokratik Partisi, HDP) supporters, Nationalist Movement Party (Milliyetçi Hareket Partisi, MHP) supporters (local out-groups) that were represented in the Grand National Assembly of Turkey by the November-2015 parliamentary elections. The main view supported by the research is that individual-based and group-based processes (personal identity and social identity; individual-based deprivation and group-based deprivation) may be simultaneously salient, overlapped (fused), and mutually supportive, and strengthen the motivation to exhibit extreme self-sacrificing behaviors to save the lives of group members.

\section{Identity-based Approach}

Since the late 1970s, in-group identification concept and Social Identity Theory (Tajfel \& Turner, 1979) has been used frequently to explain pro-group behaviors. However, the contemporary international articles use a

\author{
Türker Özkan
}

Middle East Technical University

relatively new approach, namely, Identity Fusion Theory (Swann et al., 2009; 2012) that has not been tested in a Turkish sample to predict extreme pro-group behaviors. Depending on the previously conducted studies (e.g., Buhrmester et al., 2012; Gomez et al., 2011; Swann et al., 2009; Swann \& Buhrmester, 2015; Swann, Gomez et al., 2014; Swann, Gomez, Dovidio, Hart, \& Jetten, 2010; Swann, Gomez, Huici, Morales, \& Hixon, 2010), there are some differences between in-group identification and identity fusion concepts. Functional antagonism principle and depersonalization hypothesis, discussed in the scope of Social Identity Theory, explains progroup behaviors with activation of social identity / deactivation of personal identity, and membership-based (category-based) attraction (e.g., Hogg, 1993; Hogg \& Hardie, 1991; Levine \& Crowther, 2008). On the other hand, principles of identity synergy, relational ties, and agentic personal self, discussed in the scope of Identity Fusion Theory, rationalizes pro-group behaviors with the connectedness and oneness of personal and social identities which are simultaneously salient, functionally equal, permeable, and mutually supportive (rather than conflicting with each other) (e.g., Swann et al., 2009; 2012; Swann, Wenzlaff, \& Tafarodi, 1992), and thus strengthens the willingness to exhibit extreme pro-group behaviors.

\section{Relative Deprivation-based Approach}

Relative Deprivation Theory (Crosby, 1976; Davis, 1959; Gurr, 1970; Runciman, 1966) is also used to make sense of the willingness to perform pro-group behavior. Due to the theory, individuals realize their personal disadvantages compared to other people or in-group-based disadvantages compared to other groups through interpersonal and intergroup subjective comparisons. Inter-

Address for Correspondence: Asst. Prof. Dr. Fatih Özdemir, Bursa Uludağ University, Faculty of Arts and Sciences, Department of Psychology, 16059, Nilüfer / Bursa

E-mail: psyfatihozdemir@gmail.com 
personal comparisons and individual-based deprivation are associated with individual-based outcomes as subjective well-being, life satisfaction, self-esteem, stress, and depression (e.g., Osborne \& Sibley, 2013; Smith \& Ortiz, 2002; Smith, Pettigrew, Pippin, \& Bialosiewicz, 2012; Walker, 1999; Walker \& Mann, 1987) whereas intergroup comparisons and group-based deprivation are related to group-based issues as collective action, and social change (e.g., Abrams \& Grant, 2012; Walker \& Man, 1987) in previously conducted studies.

Researchers mostly highlight the importance of same-level approach (e.g., Smith et al., 2012; Walker \& Mann, 1987; Walker \& Pettigrew, 1984), and present the individual-based and group-based deprivations as unrelated processes. It is frequently suggested that pro-group behaviors can be explained using group-based identity, intergroup comparisons and group-based deprivation (e.g., Smith et al., 2012; Walker, 1999; Walker \& Mann, 1987). This reminds the differentiation-based approach mentioned in the articles of Hogg (1987; 1991; 1993), and ignores the effects of personal identity, interpersonal comparisons, and individual-based deprivation on group-based behaviors. However, in the study conducted by Pettigrew et al. (2008), group-based deprivation mediated the relationship between individual-based deprivation and out-group prejudice. Few studies suggest that simultaneous individual-based and group-based deprivations support the willingness to exhibit pro-group behavior, and strengthen the in-group commitment (Foster \& Matheson, 1995; Tougas \& Beaton, 2002).

Due to the literature findings, the research hypotheses are listed as follows:

Hypothesis 1. Identity fusions with local in-group and extended in-group will positively predict the tendency to exhibit extreme self-sacrificing behaviors for the sake of these groups. The predictive powers of identification with local in-group and extended in-group on the tendency to exhibit extreme self-sacrificing pro-group behaviors will be lower or insignificant.

Hypothesis 2. Reletive deprivation fusion will positively predict the tendency to exhibit extreme self-sacrificing behaviors for the sake of local in-group and extended in-group. The predictive powers of separate individual-based and group-based relative deprivations on the tendency to exhibit extreme self-sacrificing progroup behaviors will be lower or insignificant.

\section{Method}

\section{Participants}

Three hundred twenty people $\left(N_{\text {female }}=219 ; N_{\text {male }}=\right.$ 101) who defined themselves as CHP supporter participated in the study. The age of participants ranged from
18 to 37 , with a mean age of $24.72(S D=4.86)$. Participants had undergraduate $(N=234)$ and graduate $(N=86)$ degrees. The mean of perceived socio-economic status in the sample was found to be $4.24(S D=.87)$ using a 7-point Likert scale.

\section{Measures}

Vignettes. Vignettes, tested the tendency to exhibit extreme self-sacrificing behaviors to save local in-group, extended in-group, and local out-group members, developed by Swann et al. (Swann, Gomez et al., 2014; Swann, Gomez, Dovidio et al., 2010). The six vignettes adapted into Turkish in this research (see Table 1). In the first-two vignettes, social identity and personal identity activations were provided, respectively, and the tendency to exhibit extreme self-sacrificing behavior (sacrificing own life) to save the lives of local in-group members (CHP supporters) was tested. The third vignette tested the extreme self-sacrificing behavior tendency to save the lives of five extended in-group members (the Republic of Turkey citizens) versus the life of a local in-group member (CHP supporters). Lastly, the fourth, fifth, and sixth vignettes measured the extreme self-sacrificing behavior tendency to save the lives of five extended ingroup members (the Republic of Turkey citizens) versus five local out-group members (AKP, HDP, and MHP supporters).

Measure of Group Identification. The 6-item scale was developed by Mael and Ashforth (1992; $\alpha=$ $.83)$ to measure the group identification. In this study, the scale adapted into Turkish (see Appendix Table 1), and participants filled out the measure to indicate what extent they identify themselves with CHP supporters and the Republic of Turkey citizens $(\alpha=.86, \alpha=.88$, respectively). Higher scores indicate stronger identification with the social group.

Identity Fusion Scale. The 7-item scale was developed by Gomez et al. $(2011 ; \alpha=.83)$ to test the individual's identity fusion with a social group. In this study, the scale adapted into Turkish (see Appendix Table 1), and participants filled out the measure to indicate what extent they feel fused with CHP supporters and the Republic of Turkey citizens ( $\alpha=.92, \alpha=.92$, respectively). Higher scores show stronger identity fusion with the social group.

Individual-based and Group-based Relative Deprivation Scale. The 5-item egoistic relative deprivation scale was developed by Özdemir, Tekeş, and Öner-Özkan $(2019 ; \alpha=.71)$ to test individual-based deprivation depending on the interpersonal comparisons. The 2-factor individual-based and group-based relative deprivation scale (see Appendix Table 1) was derived from the scale of Özdemir and colleagues (2019). Par- 
ticipants compared themselves and their local in-group (CHP supporters) with other Republic of Turkey citizens using interpersonal and intergroup comparisons, and indicated what extent they perceive individual-based and group-based deprivations depending on the possessed socio-political conditions ( $\alpha=.85, \alpha=.87$, respectively). Higher scores indicate greater individual-based and/or group-based deprivations.

Relative Deprivation Fusion Scale. The 7-item scale $(\alpha=.94)$ was developed in this research to test the connectedness and oneness of individual-based and group-based deprivations (see Appendix Table 1), considering Identity Fusion Scale (Gomez et al., 2011). Before the scale items, the participants read the definitions of individual-based and group-based relative deprivations. Higher scores mean stronger relative deprivation fusion which individual-based perceived disadvantage becomes relevant with local in-group-based perceived disadvantage, and people indicate relative deprivation in both individual and group levels.

\section{Procedure}

After the approval by the ethical review board of Middle East Technical University, the research data were collected using the QUALTRICS software. The research announcements were shared through social media channels and posted to e-mail addresses of CHP branches. The data collection process was finalized 1 day before the constitutional referendum in 2017.

\section{Results and Discussion}

Considering the descriptive findings (see Table 2), there was a strong positive association between identification and identity fusion with local in-group (CHP supporters). The similar association was found between the variables of identification and identity fusion with extended in-group (the Republic of Turkey citizens). Also, local in-group-based identity variables were positively related to extended in-group-based identity variables. When identity and relative deprivation variables were considered, identity variables indicated stronger positive associations with relative deprivation fusion compared to separate individual-based and group-based relative deprivations.

The view of "individual-based and group-based processes (personal identity and social identity; individual-based deprivation and group-based deprivation) may be simultaneously salient, overlapped (fused), and mutually supportive, and strengthen the tendency to exhibit extreme self-sacrificing pro-group behavior" and hypotheses were supported by the research findings (see Table 2; Table 3; Table 4). Identity fusion with local in-group (CHP supporters), and extended in-group (the Republic of Turkey citizens) positively predicted the tendency to exhibit extreme self-sacrificing behaviors for the sake of these groups, respectively. However, identification variables could not predict extreme self-sacrificing pro-group behaviors (Hypothesis 1). Also, relative deprivation fusion positively predicted the tendency to exhibit extreme self-sacrificing behaviors to save the lives of local in-group (CHP supporters) and extended in-group (the Republic of Turkey citizens) whereas separate individual-based and group-based relative deprivations could not predict extreme self-sacrificing progroup behaviors (Hypothesis 2).

Pro-group behaviors have been investigated with various approaches in the literature, but the motivation behind extreme pro-group behaviors as sacrificing own life for the sake of group members has not been clarified yet. In-group identification and Social Identity Theory (Tajfel \& Turner, 1979), which are frequently used to explain pro-group behaviors, could not predict the willingness to perform extreme self-sacrificing pro-group behaviors in this study. This finding shows that the literature on pro-group behaviors needs new approaches. Identity Fusion Theory (Swann et al., 2009; 2012) is a relatively new approach that is suggested to compensate the weak aspects of Social Identity Theory.

Relative Deprivation Theory (Davis, 1959; Gurr, 1970; Runciman, 1966) explains group-based behaviors with intergroup comparisons and group-based deprivation (e.g., Smith et al., 2012; Walker \& Mann, 1987). However, the findings of this study indicated that the fusion of simultaneously salient and interrelated individual-based and group-based deprivations strongly predicted the tendency to exhibit extreme self-sacrificing pro-group behaviors.

In sum, the research focuses on an important issue as the tendency to exhibit extreme self-sacrificing pro-group behaviors (sacrificing own life to save group members), and suggests that individual-based and group-based processes may be simultaneously salient, interrelated, and mutually supportive in extreme self-sacrificing pro-group behavior tendency. In spite of the its limitations (e.g., correlation-based methodology), the study contributes to the literature, and provides a useful source for individuals interested in extreme progroup behaviors (including terrorist activities), identity and deprivation processes, and socio-political environment in Turkey. 